\title{
Fusiline foraminiferal biostratigraphy and carbonate facies of the Permian Ratburi Limestone, Saraburi, central Thailand
}

\author{
O. DAWSON \\ University of London, \\ Department of Geology \\ Royal Holloway and Bedford New College \\ Egham, \\ Surrey TW20 OEX.
}

\begin{abstract}
A succession of Permian carbonates outcropping along the highway north of Saraburi, central Thailand, has yielded a prolific and diverse fusiline-algal assemblage of Early Permian (Sakmarian) to early Late Permian (Midian) age. Six major units representing dominantly carbonate platform environments are recognised: turbidite and basin slope deposits, a platform margin algal reef, a back reef, an interior platform with patch reefs, a protected lagoon inner platform, and supratidal, dolomitised algal mats. Archaeolithoporella and Tubiphytes form major reef frameworks analogous to those described from the Middle Permian reefs of Trogkofel (southern Austria) and El Capitan (western Texas). The associated dasycladacean floras are assignable to the Eastern Circum-Pacific Realm, whilst the fusiline fauna has Arctic-Tethyan affinities in the Early Permian and Tethyan affinities in the Middle Permian. Eight fusuline assemblage zones are recognised and the Robustoschwagerina-Nagatoella Zone, representing the Sakmarian (early Artinskian) stage, is recorded for the first time from central Thailand. Phylogenetic studies of the fusulines, coupled with an examination of the diagenetic fabrics and field observations, indicate the presence of an unconformity during the late Early Permian-early Middle Permian, which may be correlatable with a worldwide eustatic sea-level fall or may be due to local tectonic movements. J. Micropalaeontol., 12 (1): 9-33, August 1993.
\end{abstract}

\section{INTRODUCTION}

Permian carbonates are widespread in Thailand and form three distinct provinces: eastern, western and central (Ingavat, 1984). Saraburi, in the central province, is situated at the southern end of the Phetchabun Fold Belt which extends along the western edge of the Khorat Plateau. Studies of Permian carbonate facies in the Phetchabun Fold Belt by Dawson (1978a), Winkel et al. (1983) and Wielchowsky \& Young (1985), indicate a north-south orientated carbonate platform and basin, which swings to an east-west orientation in the south (Fig. 1). The carbonate environments around Saraburi represent from east to west: a basin slope, a marginal reef outer platform, an interior platform, and a peritidal environment. The area is strongly deformed by folding and thrusting and it is unclear whether this facies pattern reflects original palaeogeography or later tectonics.

The carbonate succession of Saraburi, often referred to as the "Saraburi Limestone" (e.g. Fontaine et al., 1986), forms the southernmost end of the Phetchabun Belt (Fig. 1), an area named the "Saraburi Zone" by Helmcke et al., (1985).

The fusulinacean foraminifera from the Ratburi Limestone in the Saraburi area have been studied previously. Toriyama et al. (1974) and Toriyama \& Kanmera (1979) established seven fusuline zones ranging in age from late Artinskian (Misellina Zone) to late Murgabian (Neoschwagerina Zone) for the

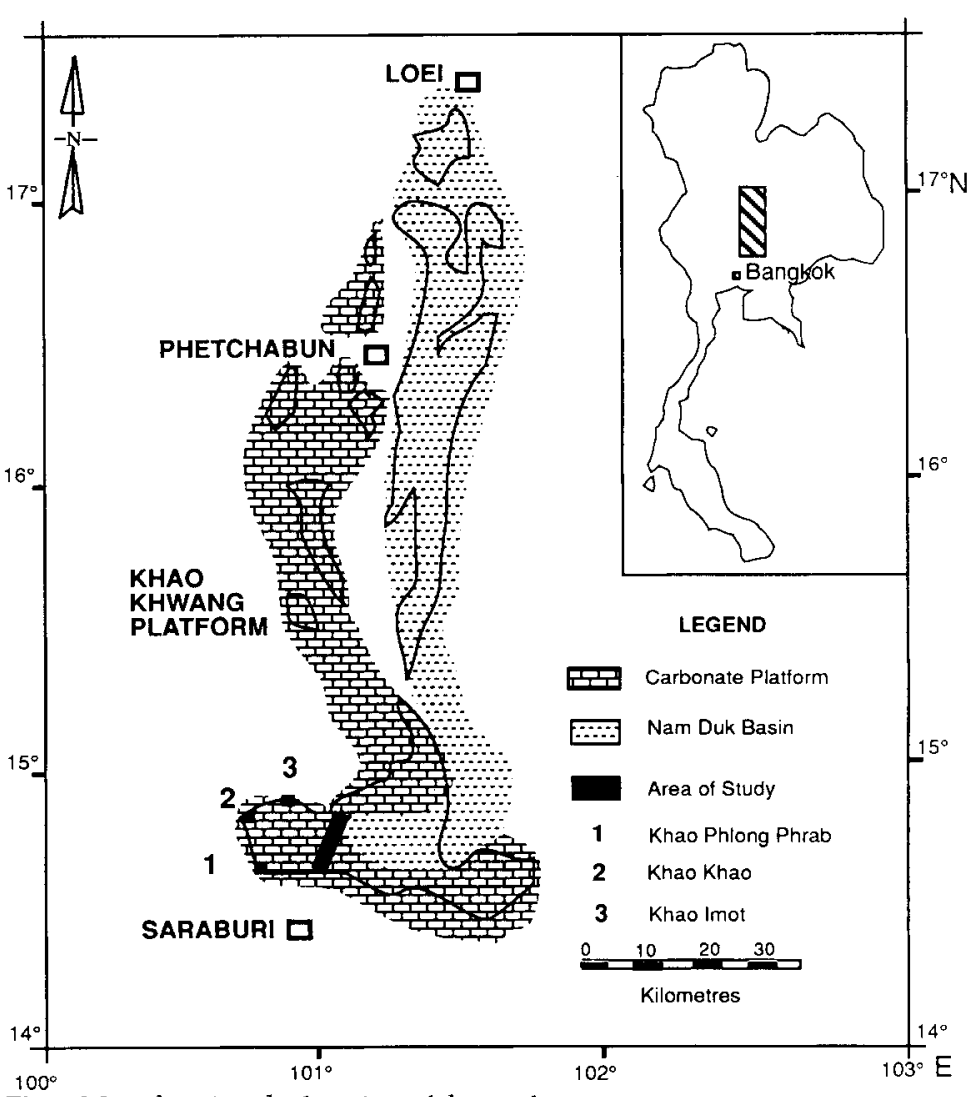

Fig. 1 Map showing the location of the study area . 


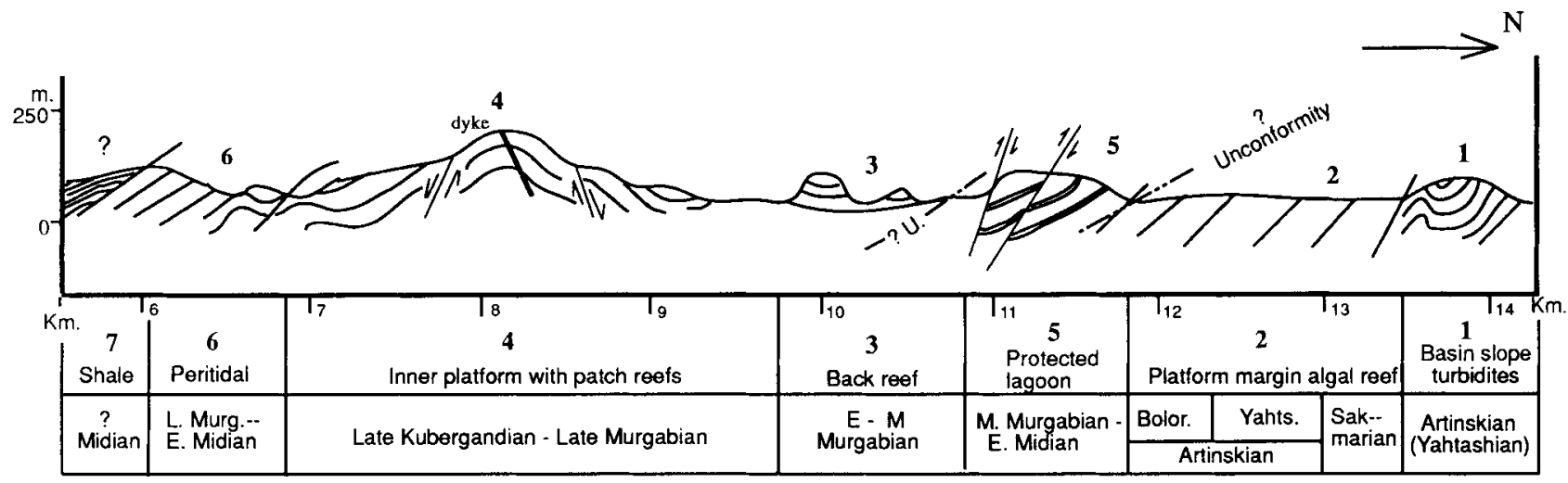

Fig. 2 Geological sketch section along highway 21, showing distribution of the six carbonate facies types (see text) and apparent conformable strata with down-fall thrust fault of Facies 5 . Facies Boundary -.. - .. - Approx position of Unconformity

Saraburi area from sections collected from Khao Phlong Phrab, Khao Khao and Khao Imot (Fig. 1). Ingavat et al. (1980) established a definitive fusuline zonation for the Ratburi Limestone in Thailand which has been widely used by subsequent authors, and is utilised herein (Fig. 6).

According to Ingavat et al. (1980) and Fontaine et al. (1986), the fusuline zones representing the Sakmarian and Yahtashian stages are absent from central Thailand (Fig. 6), although the Pseudoschwagerina Zone is generally accepted as the base of the Early Permian (Asselian) in Thailand. Ingavat \& Douglass (1981) proposed that Monodiexodina shiptoni, found in the north, should be used as zone fossil for the Yahtashian Stage (see also Fig.6).

The material for this study (Tittirananda, 1976) was collected from a road section north of Saraburi, $7 \mathrm{~km}$ east of Khao Phlong Phrab (Figs. 1, 2). The biostratigraphy has been revised and updated, and eight successive fusuline assemblage zones are proposed, encompassing the Sakmarian to early Midian stages (Early to Late Permian). A more complete biostratigraphic framework for the Permian carbonates of central Thailand has thus been established, whilst microfacies analysis has permitted the identification of six distinct environmentally controlled floral/faunal assemblages.

Representative specimens of fusulines from the study area are deposited in the collections of the Palaeontology Department, British Museum (Natural History), London.

\section{BIOSTRATIGRAPHY}

The section along highway 21, north of Saraburi (latitude $14^{\circ} 41^{\prime} \mathrm{N}$ to $14^{\circ} 44^{\prime} \mathrm{N}$, longitude $100^{\circ} 55^{\prime} \mathrm{E}$; Fig. 1), comprises approximately $1400 \mathrm{~m}$ of tectonically disturbed Permian strata. A number of thrusts and folds are developed along the section (Fig. 2). Palaeontological evidence indicates that thrust faulting has caused some repetition of the sequence. Biostratigraphic analysis of the sequence indicates that several different facies of broadly similar age, together with younger strata, have been brought together by thrusting. Seven lithofacies are distinguished from field observations, of which six are carbonate facies (Fig. 2). The depositional and diagenetic fabrics of these limestones were described in detail by Dawson (1978a) and will only be mentioned briefly herein. They show, however, that the area was subjected to eustatic fluctuations in sea level, involving vadose, subaerial, and subtidal diagenesis during and after lithification. The stratigraphy is summarised in Figs. 2 and 6.

\section{Facies 1: Siliceous microcrystalline limestone: Turbidite} and basin slope deposits (Yahtashian-Bolorian).

This facies outcrops as a small hill north of the section at the Km14 marker on the west side of the highway (Fig. 2). At least $75 \mathrm{~m}$ of thin-bedded, dark grey limestone dips SW at an angle of $60^{\circ}-80^{\circ}$. The beds comprise siliceous

\section{Explanation of Plate 1}

All figures $x 10$, except where stated.

Figs 1-3 Robustoschwagerina sp. Fig.1, subaxial section; Fig.2, axial section showing deep umbilici; Fig. 3, sagittal section showing tightly coiled juvenile whorls and long thin plane septa. Thin sections T.265a-c. Lower part of Facies 2, Sakmarian (Early Permian). All x5.

Figs 4-7 Nagatoella sp. Figs 4-6, subaxial sections showing dense chomata and relatively narrow tunnels; Fig. 7, axial section ( $x 15)$. Thin sections T.268a,b; 267c. Lower part of Facies 2, Sakmarian.

Figs 8-10 Pseudofusulina vulgaris (Schellwien). Fig. 8, oblique section; Fig. 9, sagittal section (x15); Fig.10, axial section showing highly fluted septa and prominent phrenothecae. Thin sections T.257 (Fig.8) and T.270k (Figs 9,10). Middle part of Facies 2, Yahtashian (early Artinskian), Early Permian. Fig. 11 Pseudofusulina sp. Sagittal section showing relatively thick spirotheca for size of shell. Thin section T.237. Middle part of Facies 2 . Yahtashian.

Fig.12 Schwagerina sp. Axial section. Thin section T.264. Lower part of Facies 2. Yahtashian

Figs 13-15 Chalaroschwagerina sp. Figs 13, 15, oblique sections; Fig. 14. sagittal; sections T.254, 237. Lower to middle part of Facies 2. Yahtashian. 

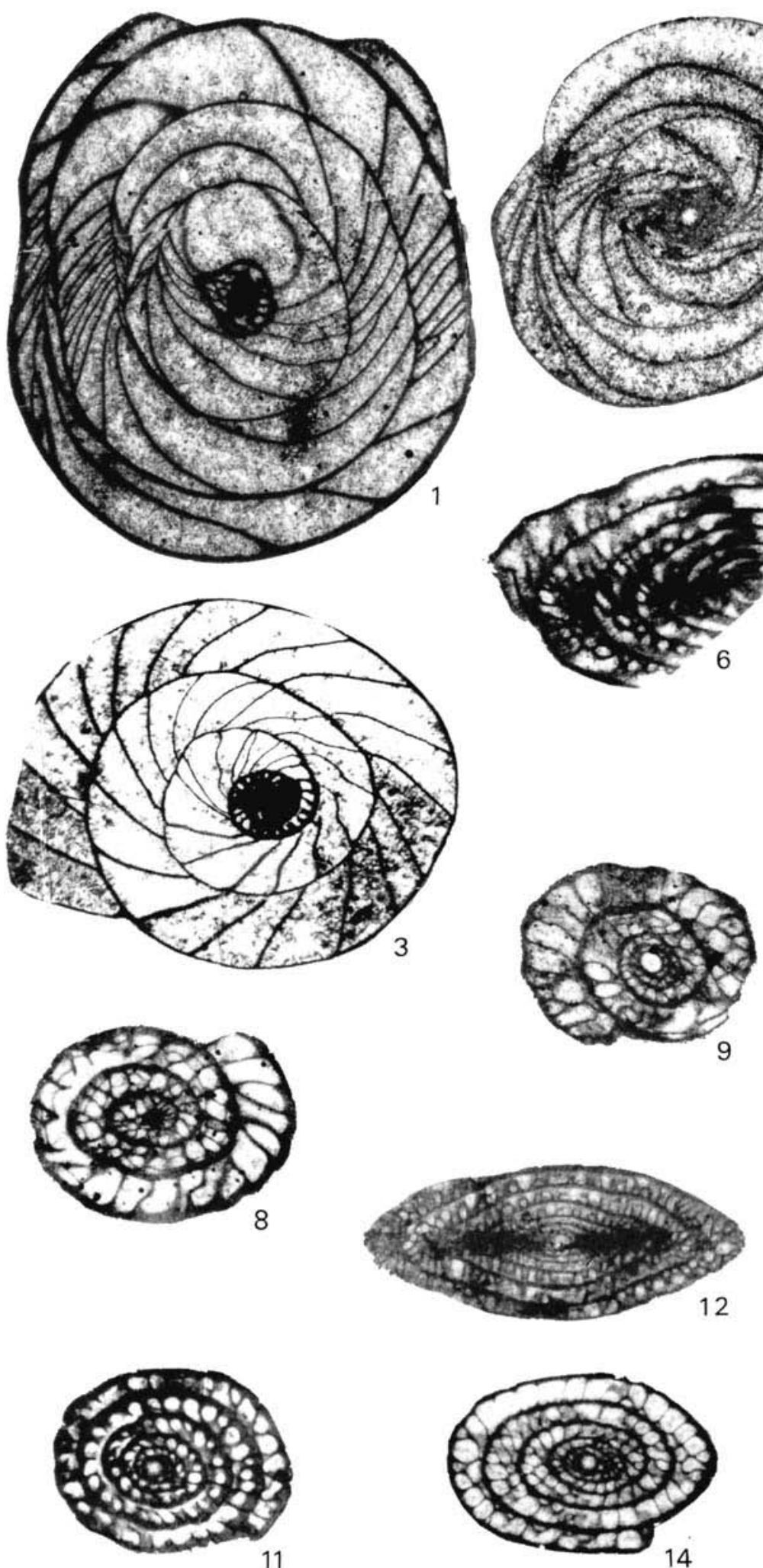
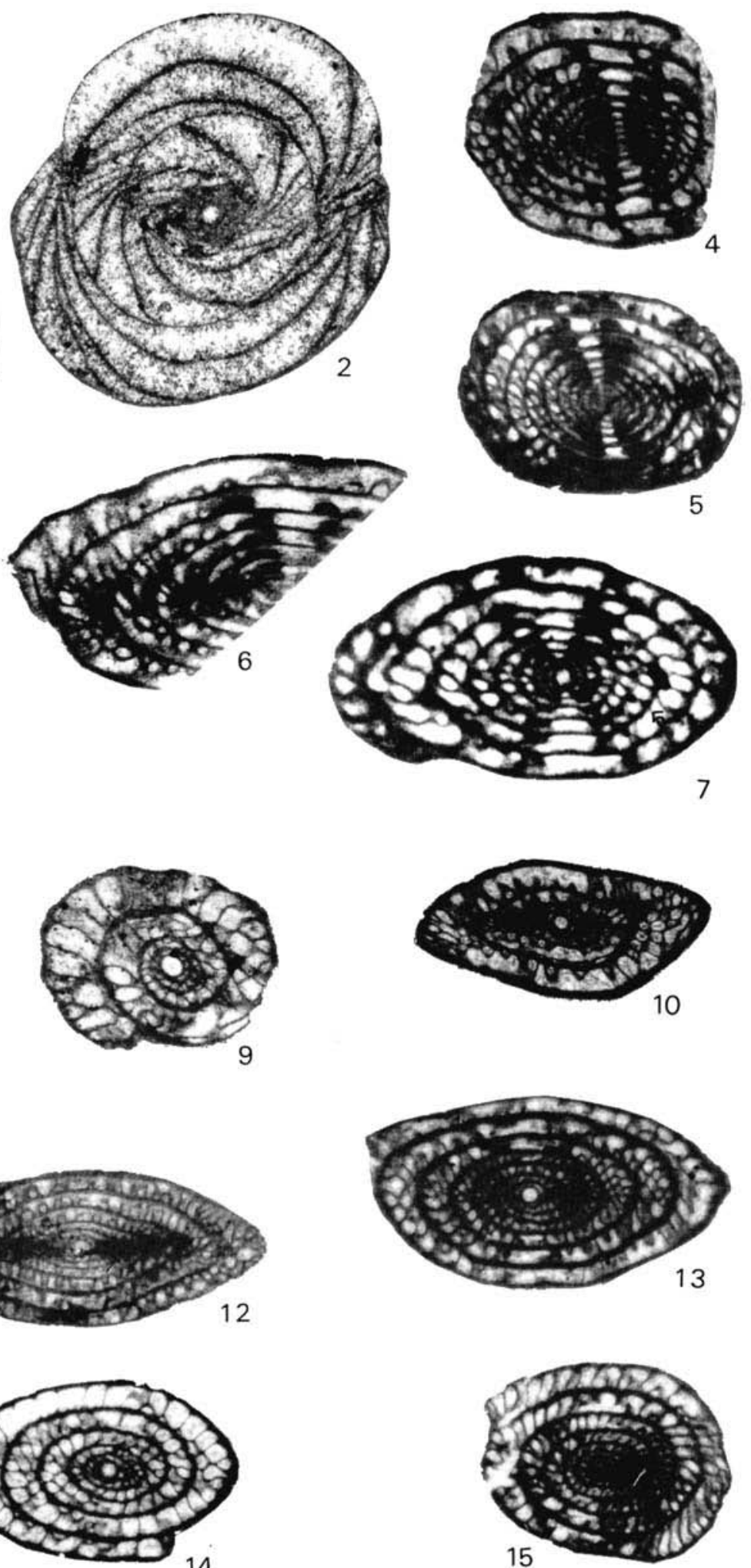
microcrystalline limestones with occasional chert nodules. Dark argillaceous chert and microcrystalline siliceous limestone dominate the lower part of the unit. Layers of chert nodules and chert bands appear to have formed through the replacement of lime mud. Some bioclasts are entirely siliceous and are encompassed within a black bituminous matrix. Traces of sponge spicules are common. The upper part of the facies $(3 \mathrm{~m})$ consists of thin-bedded bioclastic wackestones/packstones. Shell fragments and fusuline tests show abrasion and grading and many features indicative of calciturbidites, as described by Helmke and Kraikhong (1982).

Misellina, Schubertella, Mesoschubertella, Pseudofusilina, ?Neothailandina and Neofusulinella are among the few fusulines that are present in this facies, which is similar in age to the middle part of Facies 2 (see below).

Facies 2: Archaeolithoporella-Tubiphytes boundstones and skeletal grainstones: Platform margin algal biostrome (Sakmarian-Bolorian).

This facies is exposed as a limestone pavement in a paddy field and occurs structurally and in part, stratigraphically above Facies 1 . It has a minimum thickness of $630 \mathrm{~m}$. The limestone is medium to light grey, massive to thick-bedded and comprises dense microcrystalline skeletal grainstones and boundstones and lacks any mud matrix. The facies is characterised by its diverse macro- and microfauna, common algal boundstone, and an abundance of fibrous and sparry cements. The grainstone is locally dolomitised, particularly towards the top of the unit. Fusuline-algal grainstones and boundstones dominate the entire facies, whilst brachiopods, gastropods, and cephalopods are common. A few metres of a black, argillaceous bioclastic packstone occurs near the top of the section, above the dolomitised bed and has yielded a Middle Permian belemnite-like aulacocerid (Dawson, 1978b).

The lowest part of this facies contains $1.5 \mathrm{~m}$ of fusulinerich grainstones containing abundant Robustoschwagerina, Nagatoella, Toriyamaia and dasycladacean algae in the lower part; this unit represents the oldest marker bed in the section. Skeletal grains are not in contact and are bounded by Tubiphytes and other encrusting algae with masses of columnar and fibrous cements. Locally, dense micrite envelopes and Tubiphytes coat skeletal grains and are followed by syntaxial drusy and fibrous calcites in optical continuity (Pl. 9, Figs 1,2). These cement fabrics are typical of early marine cements as described from other Permian reef frameworks (Toomey \& Babcock, 1983, Flügel, 1981 and Flügel et al., 1984). The grain sorting and depositional fabrics indicate a high energy open shelf environment. Meniscus cements suggest early vadose diagenesis (Dawson, 1978a).

Robustoschwagerina is considered to be a derivative of Pseudoschwagerina (and by some authors to be a subgenus of Paraschwagerina). Facies 2 is therefore presumably younger than the Pseudoschwagerina Zone, said to be the lowest part of the Permian within the Ratburi Limestone (Ingavat et al., 1980). These beds represent the earliest dateable horizon in the limestone sequence of the Saraburi area.

The beds overlying the fusiline-rich grainstones are massive and are dominated by algal boundstones containing Archaeolithoporella and Tubiphytes together with an abundant radiaxial cement. Archaeolithoporella intergrowths with fibrous calcite and botryoidal cements may represent an altered encrusting or dome-shape organic biostromal structure. Later, radiaxial and blocky cements fill the remaining voids. These features are very similar to structures described and illustrated from the El Capital Reef, as a cemented reef framework, by Toomey \& Babcock (1983). Edwards \& Riding (1988) pointed out similar fibrous calcites from the Trogkofel reef of Austria which they interpreted as having formed through neomorphism of earlier algal skeletons. The occurrence of Archaeolithoporella and Tubiphytes boundstones, early marine cements and associated grainstones all indicate a wave-swept shelf area, as described by Toomey \& Babcock (1983) and Flügel (1981) from the El Capital limestone of the Guadalupe Mountains and the Trogkofel Limestone of the Carnic Alps, respectively. The Saraburi boundstones formed localised biostromal buildups at the platform margin and did not develop into a reef-rimmed margin to the carbonate platform (Dawson et al. in press).

\section{Explanation of Plate 2}

Fig. 1 Ozawainella sp. Axial section. Thin section T.221. Facies 2. Sakmarian (Early Permian). x25.

Fig. 2 Brevaxina cf. compressa (Deprat). Axial section. Thin section T.220. Facies 2. Bolorian, Misellina Zone (early Mid-Permian). x20.

Fig.3 Minojapanella cf. elongata Fujimoto \& Kanmera. Axial section. Thin section T.222. Middle part of Facies 2. Sakmarian/Yahtashian (Early Permian). $\times 25$.

Fig. 4 Toriyamaia sp. Oblique section. Thin section T.275. Facies 2. Sakmarian. x25.

Figs 5-7 Misellina otai Sakagushi \& Sugano. Figs. 5,6, axial sections; Fig. 7, sagittal section. Thin section T.277k. Facies 2. Bolorian, Misellina Zone. $\mathrm{L} \times 25$.

Fig.8 Misellina ovalis (Deprat). Tangential section. Thin section T.269k. Top of Facies 2. Bolorian. $\times 25$.

Fig. 9 Misellina confragaspira (Leven). Axial section. Thin section T.270d. Upper part of Facies 2. Bolorian. $\times 20$.

Fig.10 Misellina sp. Sagittal section. Thin section T.270d. Upper part of Facies 2. Bolorian. x20.

Fig.11 Armenina sp. Subaxial section. Thin section T.215b. Upper part of Facies 2. Bolorian. x20.

Fig,12 Schubertella sp. Axial section. Thin section T.270h. Facies 2. Yahtashian (Early Permian). x25.

Fig.13 Staffella sp. Axial section. Thin section T.270k. Facies 2. Yahtashian. x10.

Fig.14 Sphaerulina sp. Axial section. Thin section T.201, Facies 2. Yahtashian/Bolorian. x15. 

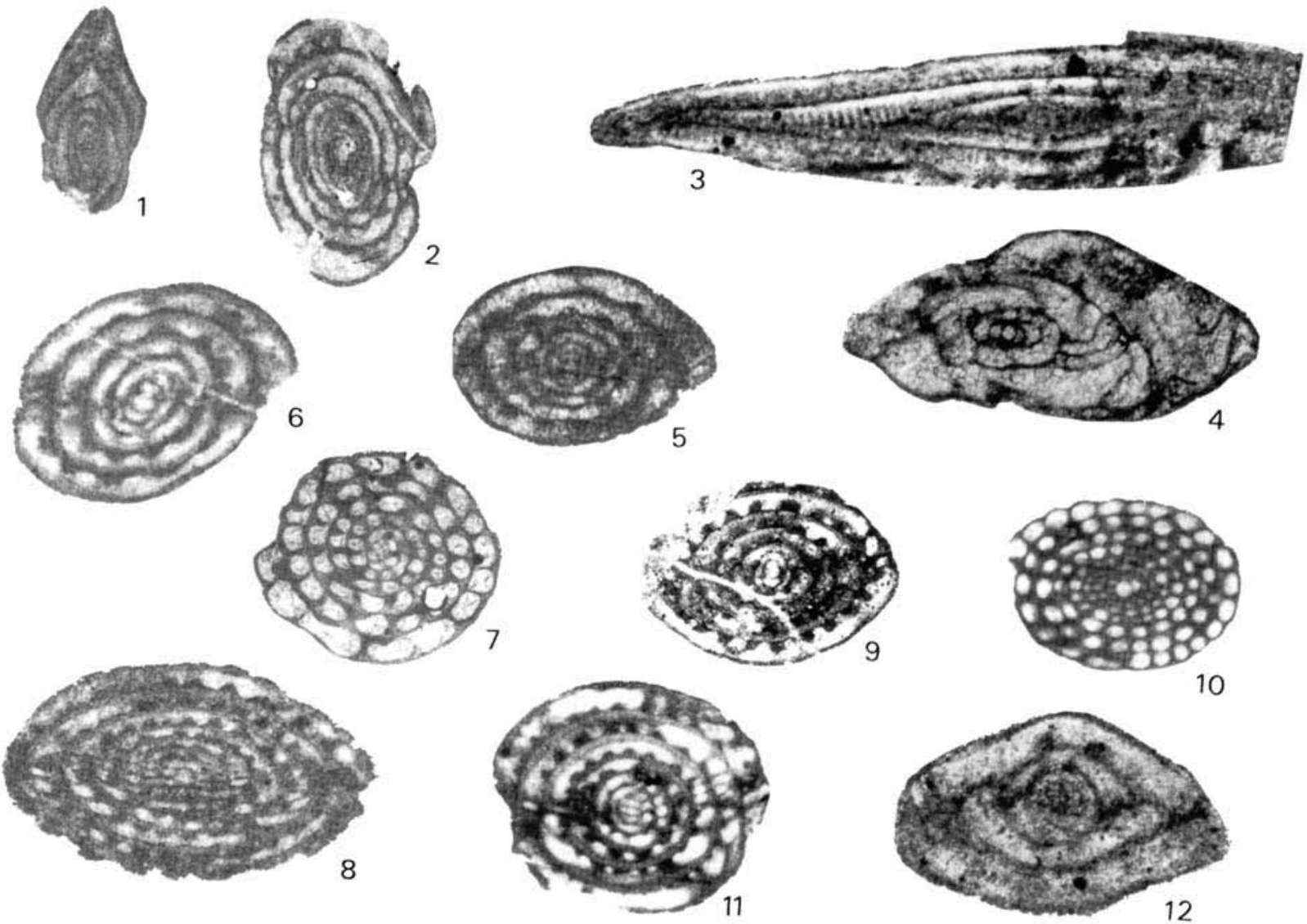

10
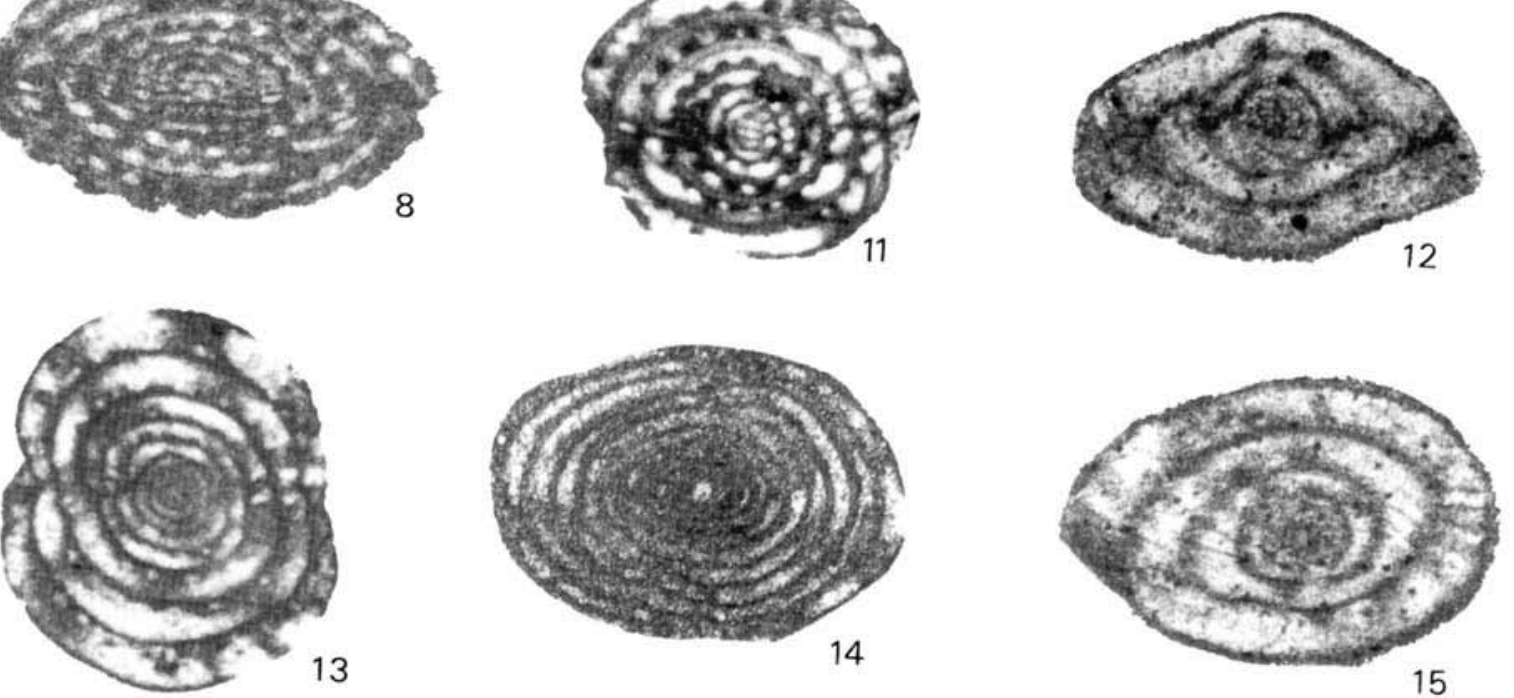


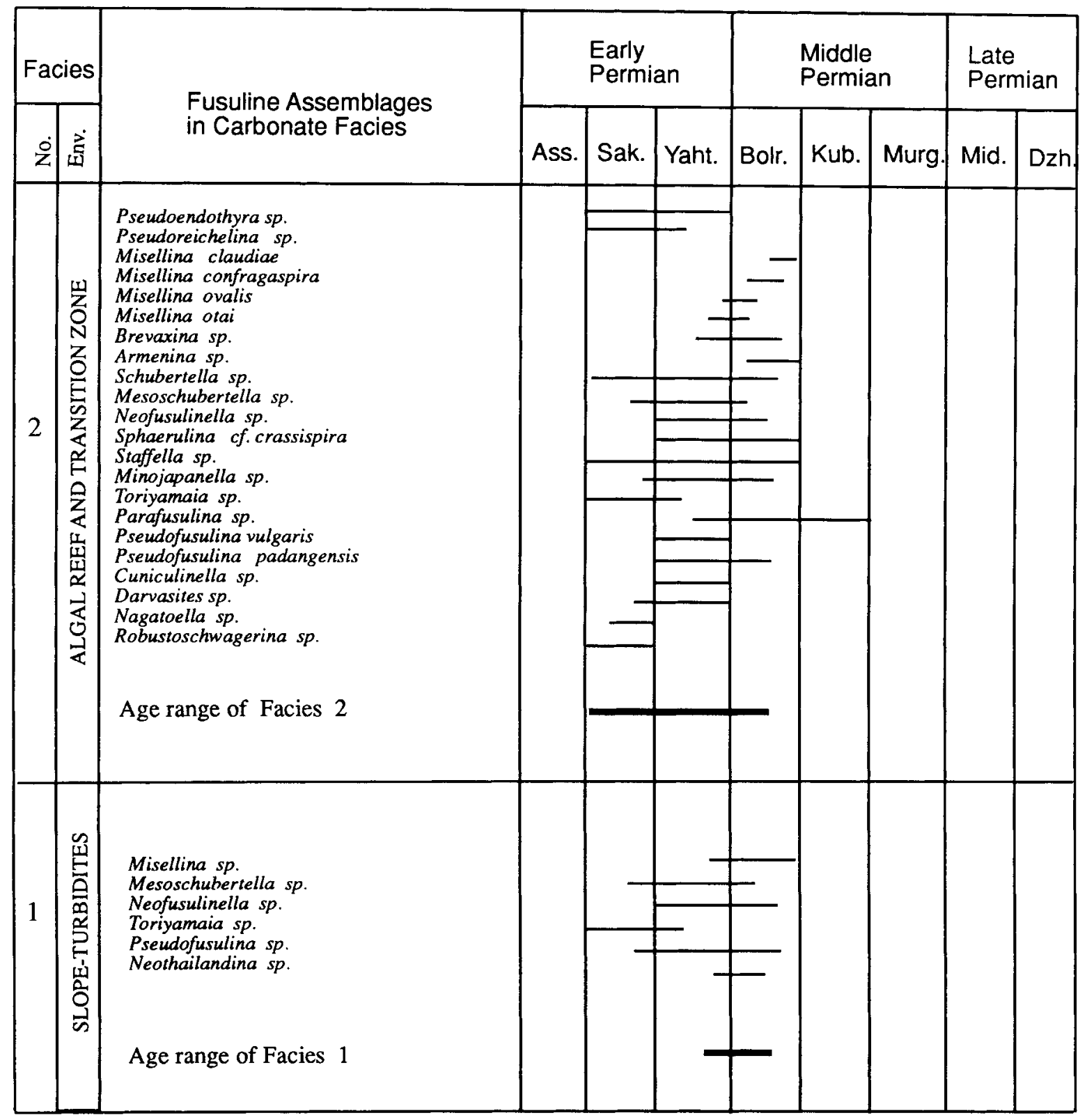

Fig. 3 Fusuline assemblages of Facies 1 and 2, showing stratigraphic ranges of species; Sakmarian-early Bolorian (Early Permian-early Middle Permian).

\section{Explanation of Plate 3}

All figures $\times 10$, except where stated

Fig. 1 Parafusulina kaerimizensis (Ozawa). Axial section. Thin section T.237. Lower part of Facies 3. Kubergandian (Middle Permian). Figs 2, 5 Pseudofusulina sp. Subaxial sections. Thin section T.270k. Facies 2. Yahtashian (Early Permian).

Figs 3, 4 Pseudofusulina padangensis (Gübler). Fig. 3, axial section. Thin section T.529. Lower part of Facies 3; Fig. 4, tangential section. Thin section T.275. Upper part of Facies 2. Bolorian-Kubergandian (Parafusulina Zone), Middle Permian.

Figs 6, 7 Chusenella cf. alpina (Kochansky-Devidé \& Ramovs). Axial section. Thin section T.328a,b. Lower part of Facies 5. Kubergandian (Parafusulina/Cancellina Zone).

Fig. 8 Chusenella cf. schwagerinaeformis Sheng. Axial section. Thin section T.510. Facies 3. Kubergandian/Murgabian (Middle Permian).

Fig. 9 Verbeekina (Paraverbeekina) sp. Tangential section. Thin section T.411. Facies 3. Kubergandian.

Fig. 10 Verbeekina (Armenina) cf. pontica (Miklukho-Maklay). Axial section. Thin section T.408. Lower part of Facies 3. Kubergandian/Murgabian. $\mathrm{x} 5$. 

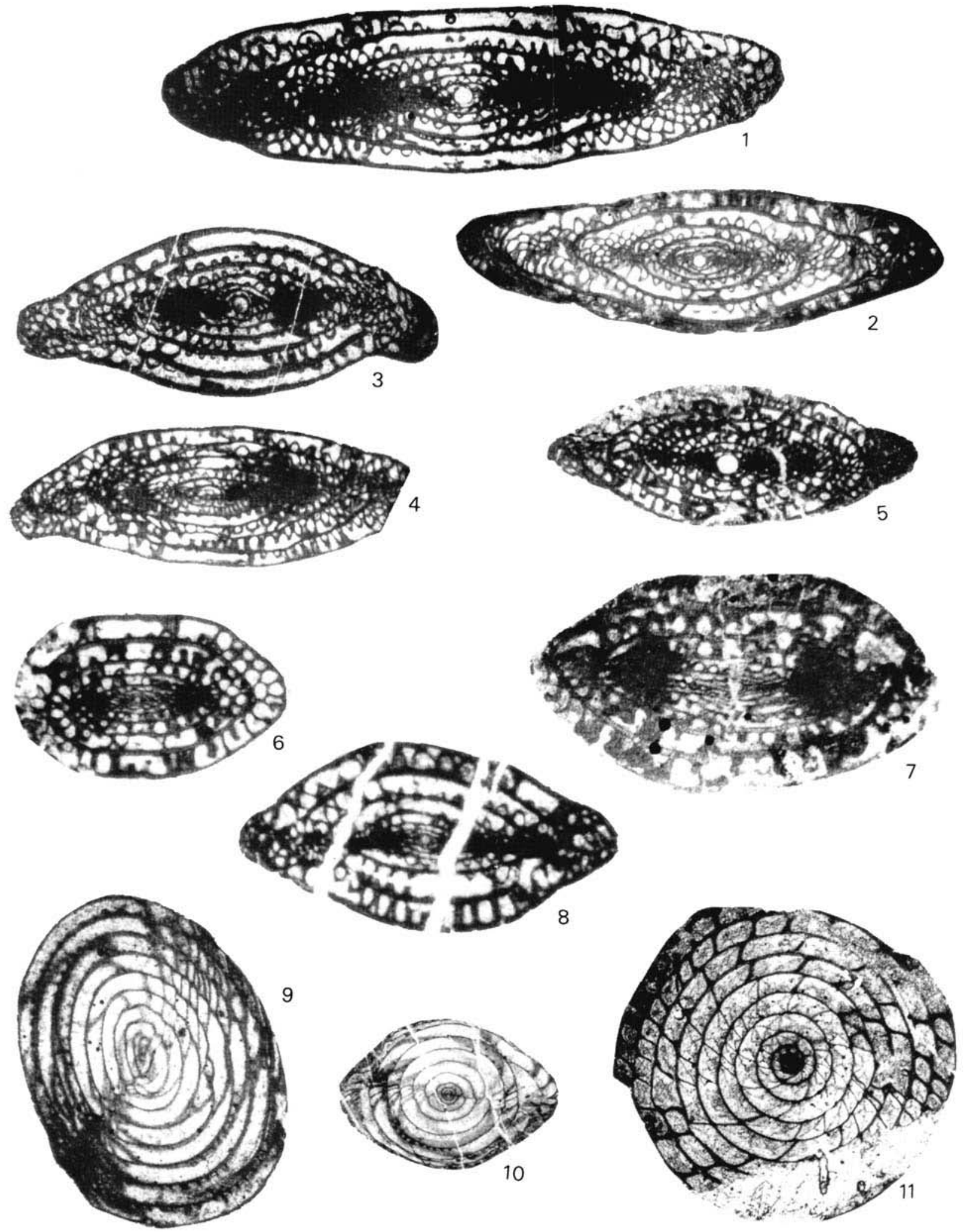
The dasycladacean algal diversity in this facies is similar to that described from Trogkofel (Flügel, 1985), Japan and Thailand (Endo, 1969), and indicates the presence nearby of shelf lagoons with both protected and open marine areas (Flügel, 1985). The dasycladaceans Anthracoporella, Vermiporella, Gyroporella, Clavaporella and Mizzia are commonly associated with textulariids and fusuline foraminifera.

Above these boundstones the rest of Facies 2 grades into grainstones, packstones and rudstones with fusulines, dasycladacean algae and echinoderm fragments as the main bioclasts. Occasionally, Tubiphytes and Archaeolithoporella occur as stabilising binding elements.

Pseudofusulina vulgaris (Schellwien) and P. padangensis (Gübler), are associated with Toriyamaia, Minojapanella, Schubertella, Cuniculinella, Chalaroschwagerina, Schwagerina, Pseudoreichelina, Pseudoendothyra and primitive species of Misellina. Pseudofusulina gradually disappears towards the middle of the facies, with increasing abundance of more advanced species of Misellina towards the top. Misellina otai Sakagushi \& Sugano, M. confragaspira (Level) and $M$. ovalis (Deprat) are common through the remainder of the facies and are often associated with Sphaerulina cf. crassispira (Deprat), the genera Minojapanella, Pseudoreichelina, Brevaxina, Armenina, Ozawainella and some species of Pseudofusilina and Parafusulina. Representative fusuline assemblages are shown in Fig. 3, with the age ranges of Facies 1 and 2.

Facies 3: Mixed fauna floatstones and packstones: Back reef, interior platform (early-middle Murgabian).

Facies 3 outcrops as small hills of thin bedded subhorizontal limestone at $\mathrm{Km} 10$ west of the highway and has a minimum thickness of $56 \mathrm{~m}$. A brecciated limestone with a reddish silty matrix appears at the base. The limestone clasts contain species of Misellina, Schubertella and Armenina, which are probably derived from the Facies 2 fauna (Yahtashian-Bolorian).

The limestone contains enormous (up to $1.5 \mathrm{~m}$ long) bivalves referable to Alatyoconcha (=cf. Tanchintongia). Shells replaced by sparry calcite are common and occur with waagenophyllid coral colonies in growth position. This mixed fauna floatstone is interbedded with fusulinedasycladacean packstones/grainstones. Large bioclasts are commonly silicified and large chert nodules are common throughout the section. This particular deposit is similar to the mixed fauna back-reef interior platform facies reported from the Ratburi area by Baird (1990).

The facies is dominated by an assemblage of Parafusulina gigantea (Deprat), Chusenella and its associated species. Neoschwagerina simplex Ozawa and Afghanella megaspherica Sheng are common in the lower part, whilst Neoschwagerina craticulifera (Schwager) and Afghanella pesuliensis (Ozawa \& Tobler) are abundant in the upper part. The smaller foraminifera Hemigordius, Cribrogenerina and Climacammina are also common as finer bioclasts. The occurrence of $N$. simplex and $A$. megaspherica suggests that this facies can be correlated with the Neoschwagerina simplex Zone of the early Murgabian (Middle Permian). The upper part of Facies 3 (Fig. 6), however, also ranges up into the middle Murgabian, as evidenced by an association of Neoschwagerina craticulifera (Schwager) and Afghanella pesuliensis (Ozawa \& Tobler). The representative fusuline assemblages of Facies 3, together with those of Facies 4, are given in Fig. 4.

\section{Facies 4: Coral-bryozoan boundstones/packstones: Interior platform with patch reefs (late Kubergandian-late Murgabian).}

These limestones outcrop along the road section between $\mathrm{Km} 7$ and 9, in a NE-SW striking anticline structure with dips at $30^{\circ}-45^{\circ}$ S-N. Faulting and folding has led to a repetition of part of Facies 4 (Fig. 2), however, the biostratigraphy has helped minimise correlation problems. The limestones are dark grey, thick-bedded bioclastic wacke/packstones with a carbonaceous-rich lime-mud matrix. Coral and sponge colonies are common, occasionally forming $1 \mathrm{~m}$ to $3 \mathrm{~m}$ high mounds or patch reefs. Brachiopods and gastropods are also abundant throughout the facies. Its minimum thickness is approximately $280 \mathrm{~m}$.

Facies 4 comprises at least three microfacies arranged in shallowing upwards cycles. Each cycle starts with a bioclastic limestone which grades upwards from wackestone to packstone, to grainstone, passing up into floatstone with a microlaminated algal stromatolite capping each cycle. Waaganophyllids, lonsdaloids and solitary corals occur in growth position in the floatstones together with bryozoan fragments. Dasycladacean algae and

Explanation of Plate 4

All figures $x 10$, except where stated.

Figs 1, 2 Neoschwagerina simplex Ozawa. Axial and sagittal sections, respectively. Thin sections T.602a,b. Lower part of Facies 4 . Early Murgabian (Neoschwagerina simplex Zone), early Middle Permian. Both x15.

Figs 3-5 Neoschwagerina craticulifera (Schwager). Fig. 3, axial section. Thin section T.621; Figs 4,5, oblique sagittal sections. Thin sections T.632a,b. Both from middle part of Facies 4. Middle Murgabian (Neoschwagerina craticulifera Zone), Middle Permian.

Figs 6, 8 Neoschwagerina cheni Sheng (N. margaritae group). Sagittal sections. Thin sections T.5506b and T.621a,b, respectively. Upper part of Facies 4. Late Murgabian (Neoschwagerina margaritae Zone), late Middle Permian.

Fig. 7 Neoschwagerina cf. haydeni (Doutkevitch \& Khabov). Sagittal section. Thin section T.527. Upper part of Facies 3. Late Murgabian. Figs 9-11 Colania douvillei (Ozawa). Figs 9,11, oblique sections. Thin sections T.527a, 529 respectively. Fig.10, tangential section. Thin section T.526. Both from upper part of Facies 4. Late Murgabian (Neoschwagerina margaritae Zone). 

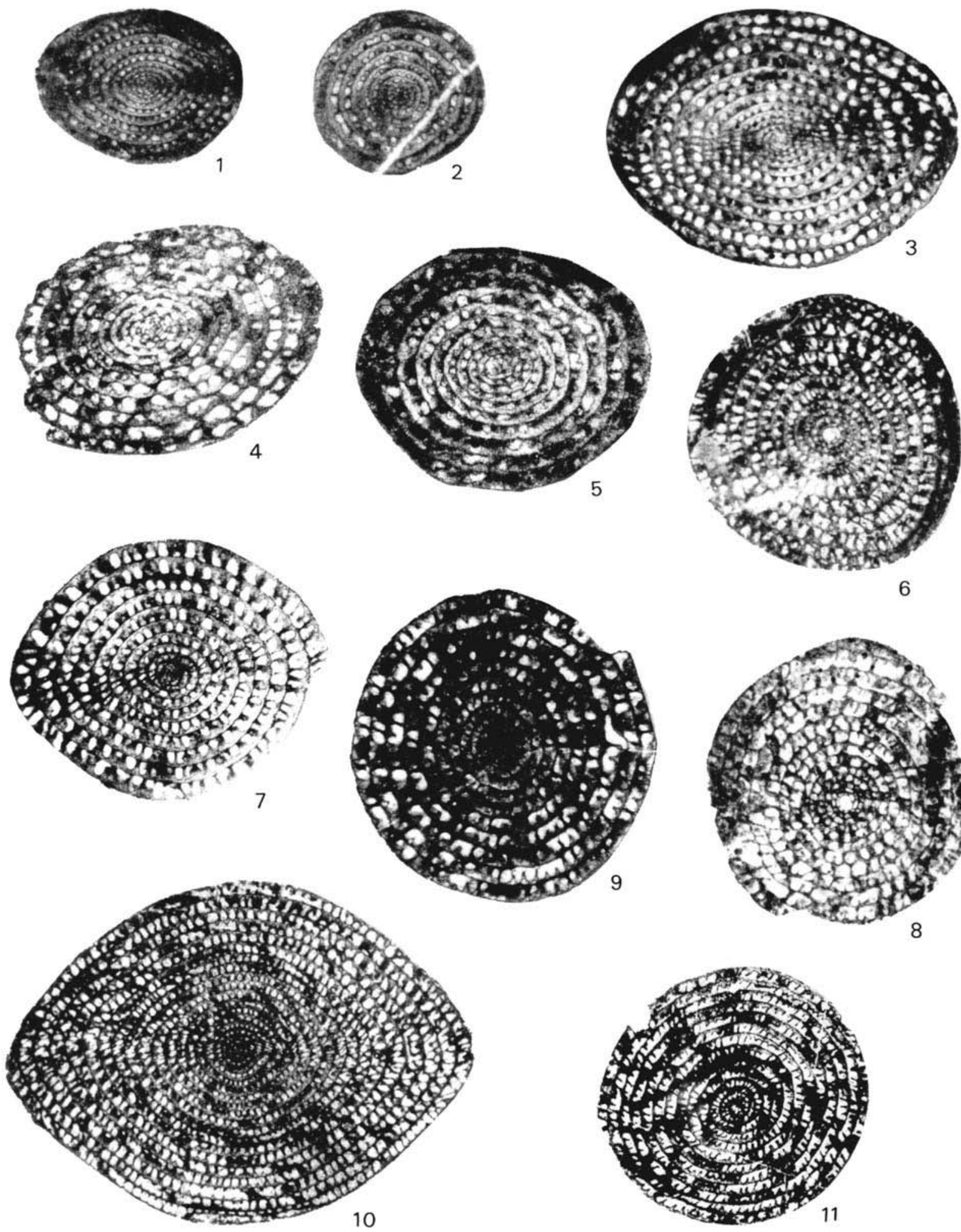

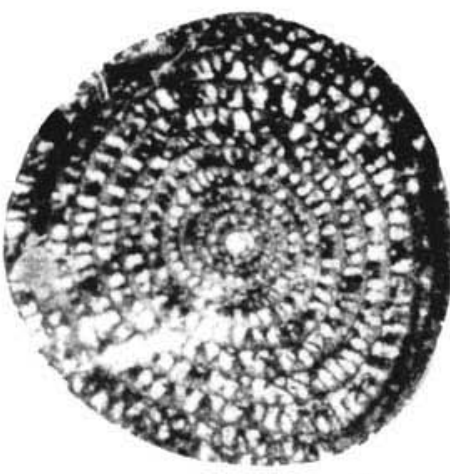

6
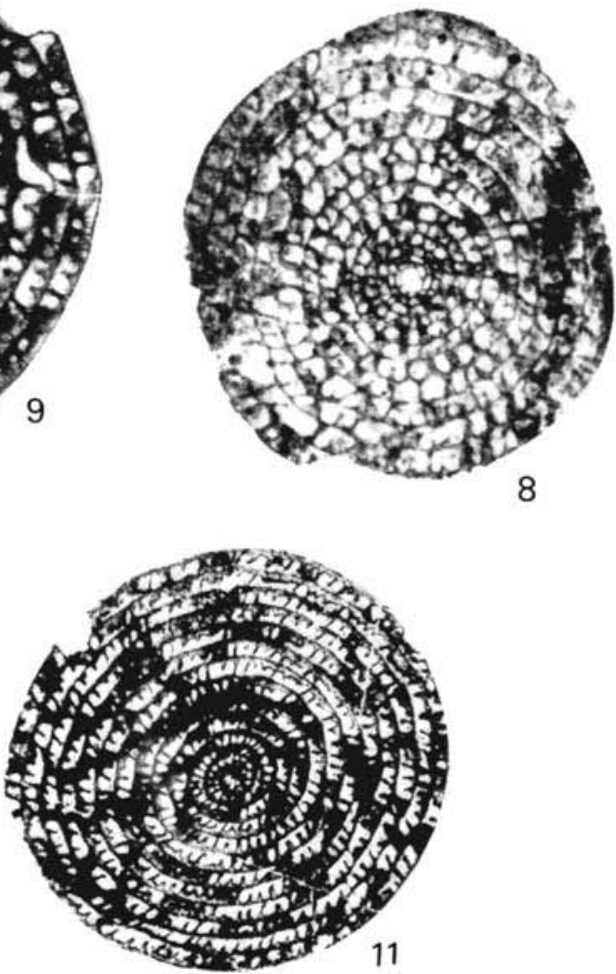


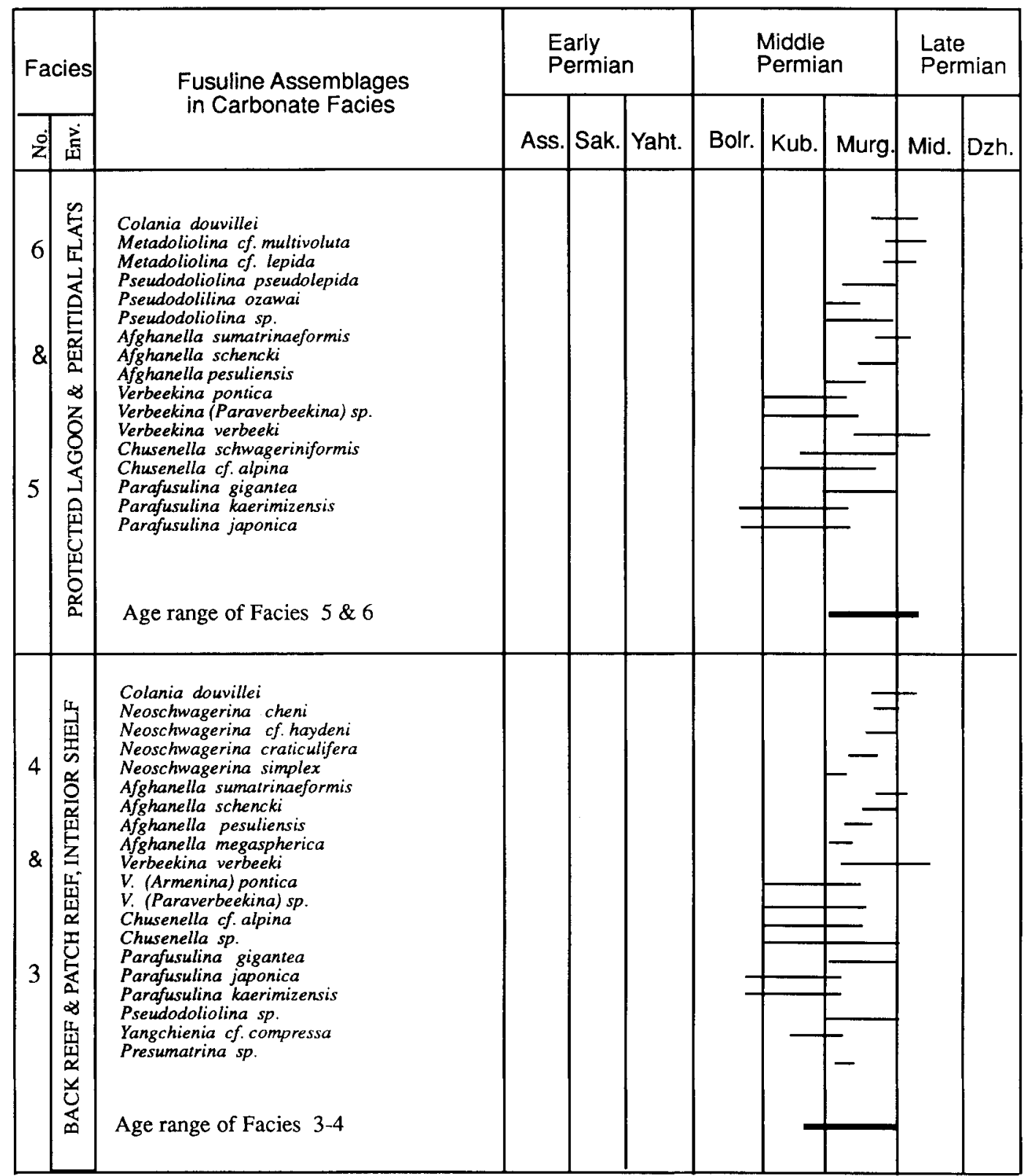

Fig. 4 Fusuline assemblages of Facies 3-6, showing stratigraphic ranges of species; late Kubergandian-early Midian (Middle Permian-early Late Permian). Note that Neoschwagerina and Pseudodoliolina dominate in different facies. Age ranges after Ozawa (1970a) and Kanmera et al. (1976).

\section{Explanation of Plate 5 \\ All figures $x 15$, except where stated}

Figs 1,7.8 Afghanella pesuliensis(Ozawa \& Tobler). Fig.1, sagittal, tangential and oblique axial sections in rock (x10); Fig.7, sagittal section; Fig.8, oblique axial section. Thin sections T.VI-7a, T.612, 615 respectively. Facies 4 Neoschwagerina craticulifera Zone, mid-Murgabian (Middle Permian). Figs 2,3 Colania sp. Oblique axial and tangential sections. Thin sections T.615b (Facies 4) and T.501a (Facies 3). Late Murgabian.

Figs 4-6 Afghanella megaspherica Sheng. Figs 4,6, axial sections. Thin sections T.504a, 514b; Fig.5, sagittal section. Thin section T.508k. Facies 3. Neoschwagerina simplex Zone, early Murgabian.

Figs 9,10 Afghanella schencki Thompson. Axial and sagittal sections. Thin sections T.303, 319 respectively. Middle part of Facies 5. Neoschwagerina craticulifera Zone, mid-Murgabian.

Figs 11,12 Afghanella sumatrinaeformis (Gübler). Axial and sagittal sections. Thin section T.615c Upper part of Facies 4. Neoschwagerina margaritae Zone, late Murgabian. Both $\times 30$. 

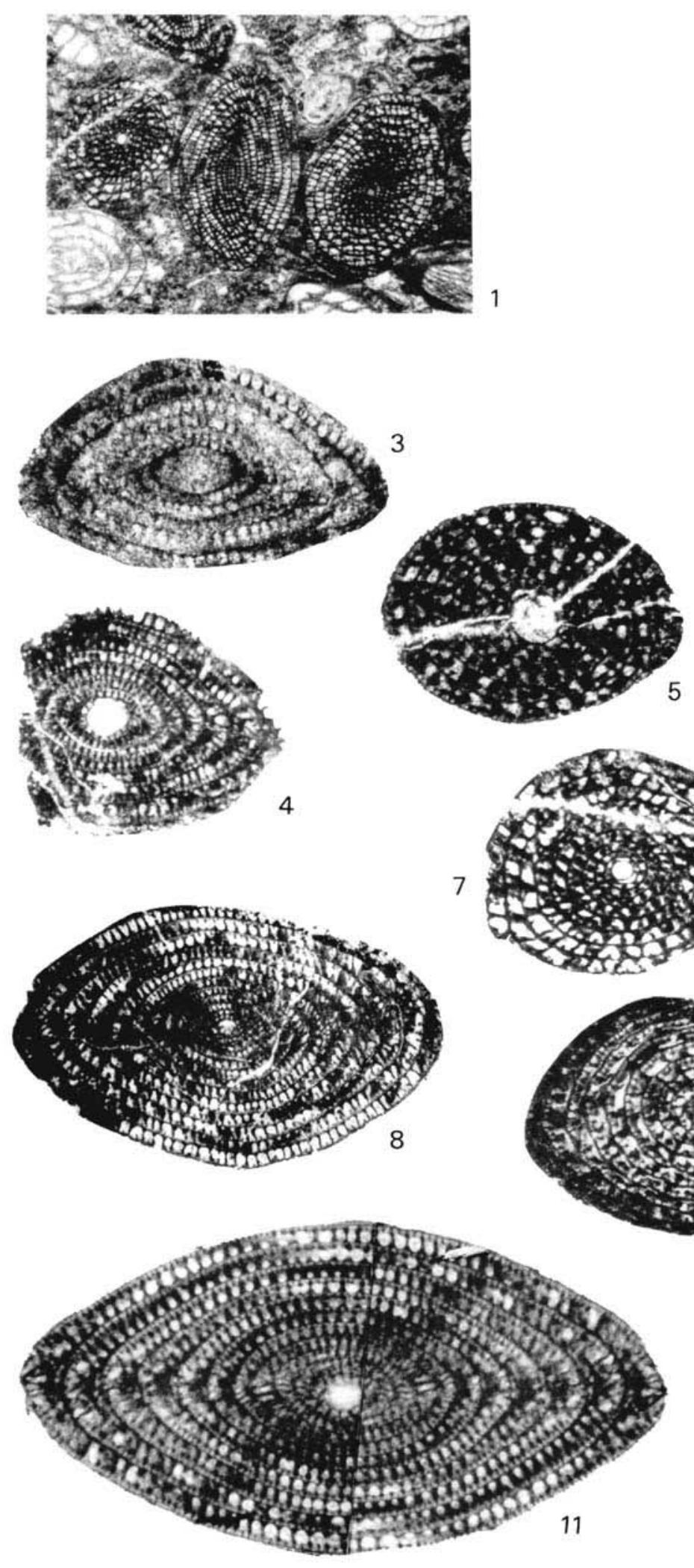
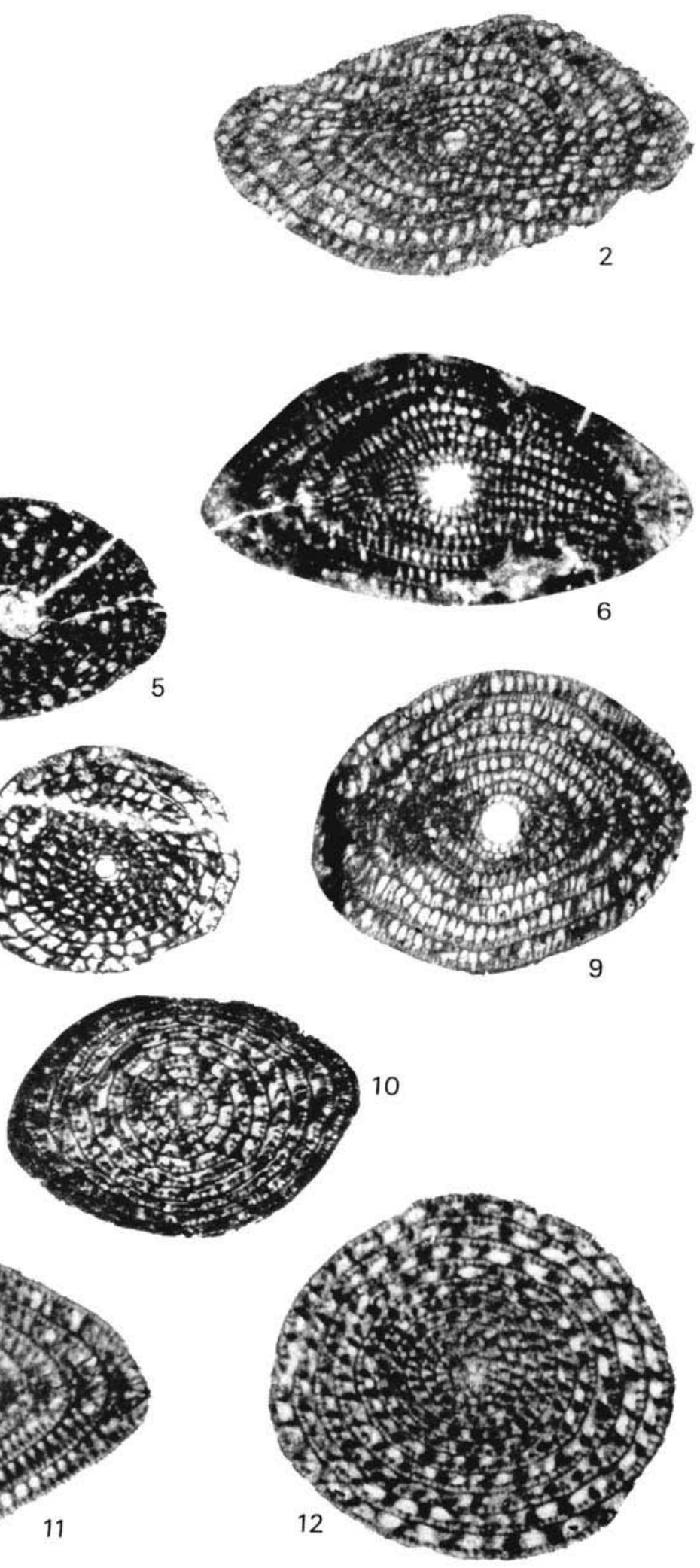
encrusting Tubiphytes are common in the boundstones and packstones, suggesting deposition in an inner platform environment. Brachiopod, gastropod, echinoid and crinoid fragments are locally present. Large botryoids of replacive sparry calcite are believed to be due to the replacement of dome-shaped algal mounds (cf. Edwards \& Riding, 1988), suggesting the presence of algal bioherms in this inner platform environment.

The upper part of Facies 4 has a dark carbonaceous matrix and is often associated with algal mats and algal peloids, suggesting deposition in a restricted, peritidal environment. The presence of carbonaceous-rich material also suggests a rather restricted shallow marine environment and this is supported by the occurrence of Permian plant fossils nearby (Campbell \& Ingavat, 1972). In contrast, the rich biotas in the lower part of this facies suggest deposition mainly in a shallow, open marine platform environment. Fusulines are diverse and abundant in grainstones and boundstones, but show low diversity in the wacke/packstones with a carbonaceous matrix. Verbeekina and some species of $p_{\text {seudodoliolina and }}$ Afghanella seem to survive into the restricted shallower marine environment of Facies 5. Overall, this facies represents shallowing from a bioherm inner platform, to restricted lagoonal and peritidal environments.

Two fusuline assemblages can be recognised: ParafusulinaChusenella-Pseudodoliolina and Neoschwagerina-Afghanella. The Parafusulina-Chusenella-Pseudodoliolina assemblage is common to the lower part of Facies 3,4 and 5, and can be used for correlation of time equivalent facies. In this assemblage Parafusulina gigantea (Deprat) and Pseudodoliolina ozawai Yabe \& Hanzawa are abundant, together with Chusenella and Verbeekina (Paraverbeekina). Representative species of Presumatrina and Maklaya also occur. The Neoschwagerina-Afghanella assemblage occupies the upper part of Facies 3 \& 4, together with Verbeekina verbeeki (Geinitz), Colania, Metadoliolina and other foraminifera.

The faunal assemblages indicate an age range from the Parafusulina Zone (= Cancellina Zone) of the Kubergandian stage, to the Neoschwagerina Zone, of the Murgabian stage (Middle Permian).

Facies 5: Interbedded shales, skeletal peloidal wacke/packstones: Protected lagoon inner platform (Murgabian-early Midian).

The facies outcrops as a small hill forming part of the Khao
Khiero range (Fig. 2) extending east-west to Phra Phuttabat at $\mathrm{Km} 11$ on the western side of the highway. The road cut is $20 \mathrm{~m}$ high and $800 \mathrm{~m}$ long. Beds strike at $125^{\circ}$ and dip south at about $50^{\circ}$. Faults occurring in the middle of the outcrop cause bedding dips to become more gentle $\left(15^{\circ}\right)$. The minimum tectonic thickness of this unit is about $100 \mathrm{~m}$.

It comprises beds of dense, dark grey medium to coarse-grained carbonaceous rich bioclastic-peloidal wacke/packstone, with argillaceous patches, interbedded with yellowish shale beds. There are four calcareous shale beds, 3 to $8 \mathrm{~m}$, apart, in the section. Slabs of waagenophyllid coral occur one metre above the third shale bed from the bottom. Based on the fusuline assemblages, the waagenophyllids can be correlated with the corals of Facies 3 and 4 . Productids, rhynchonellids and gastropods occur sparsely throughout this facies. Phylloid algae occasionally formed small mounds which have a peloidal matrix.

Parafusulina, Verbeekina, Chusenella, Pseudodoliolina and Afghanella form the main assemblage and occur in abundance throughout the facies, permitting correlation with Facies 3 and 4, as mentioned above. Near the top, species of $P$ seudodoliolina show signs of abrasion, suggesting some transportation and the tests of associated species of $V$. verbeek $i$ are often crushed. These features also occur within the equivalent assemblage in Facies 6 and have been reported from Khao Khao, to the southwest of the area (Toriyama, 1978) and from molasse-type PseudodoliolinaVerbeekina limestones, south of Phetchabun, NE Thailand (Helmcke \& Kraikhong, 1982).

Representative species of Metadoliolina first appear in the middle and top part of the unit. The palaeotextularid foraminifera, Cribrogenerina, Climacammina, Geinitzina and Pachyphloia are common as finer bioclasts.

The microfauna can be divided into two assemblages based on age and facies: Parafusulina gigantea-ChusenellaPseudodoliolina; and Verbeekina verbeeki-PseudodoliolinaMetadoliolina.

Verbeekina and Parafusulina do not occur together. Advanced species of Neoschwagerina and Afghanella appear in the middle part of the unit, in association with Parafusulina gigantea (Deprat), suggesting the facies is assignable to the Neoschwagerina Zone (Murgabian). However, the appearance of Metadoliolina cf. lepida (Schwager) indicates that it may extend into at least the lower part of the Midian stage of the Late Permian (Yabeina Zone).

The Parafusulina-Chusenella-Pseudodoliolina assemblage, in

Figs 1,2 Metadoliolina cf. lepida (Schwager). Sagittal and axial sections. Thin sections T.328a,b. Upper part of Facies 5. Neoschwagerina margaritae Zone, late Murgabian (late Mid-Permian).

Fig.3 Metadoliolina cf. pinguis Toriyama \& Kanmera. Oblique section. Thin section T.714. Middle part of Facies 6. Late Murgabian.

Figs 4-8 Pseudodoliolina pseudolepida (Deprat). Figs 4,5,7, axial sections ( $x 20$ ); Figs 6,8, sagittal sections. Thin sections T.318a,b, 714c,d. Facies 5 and 6. Neoschwagerina simplex-N. craticulifera zones. Murgabian.

Fig. 9 seudodoliolina ozawai Yabe \& Hanzawa. Oblique axial section. Thin section T.315b. Facies 5. Early Murgabian. 

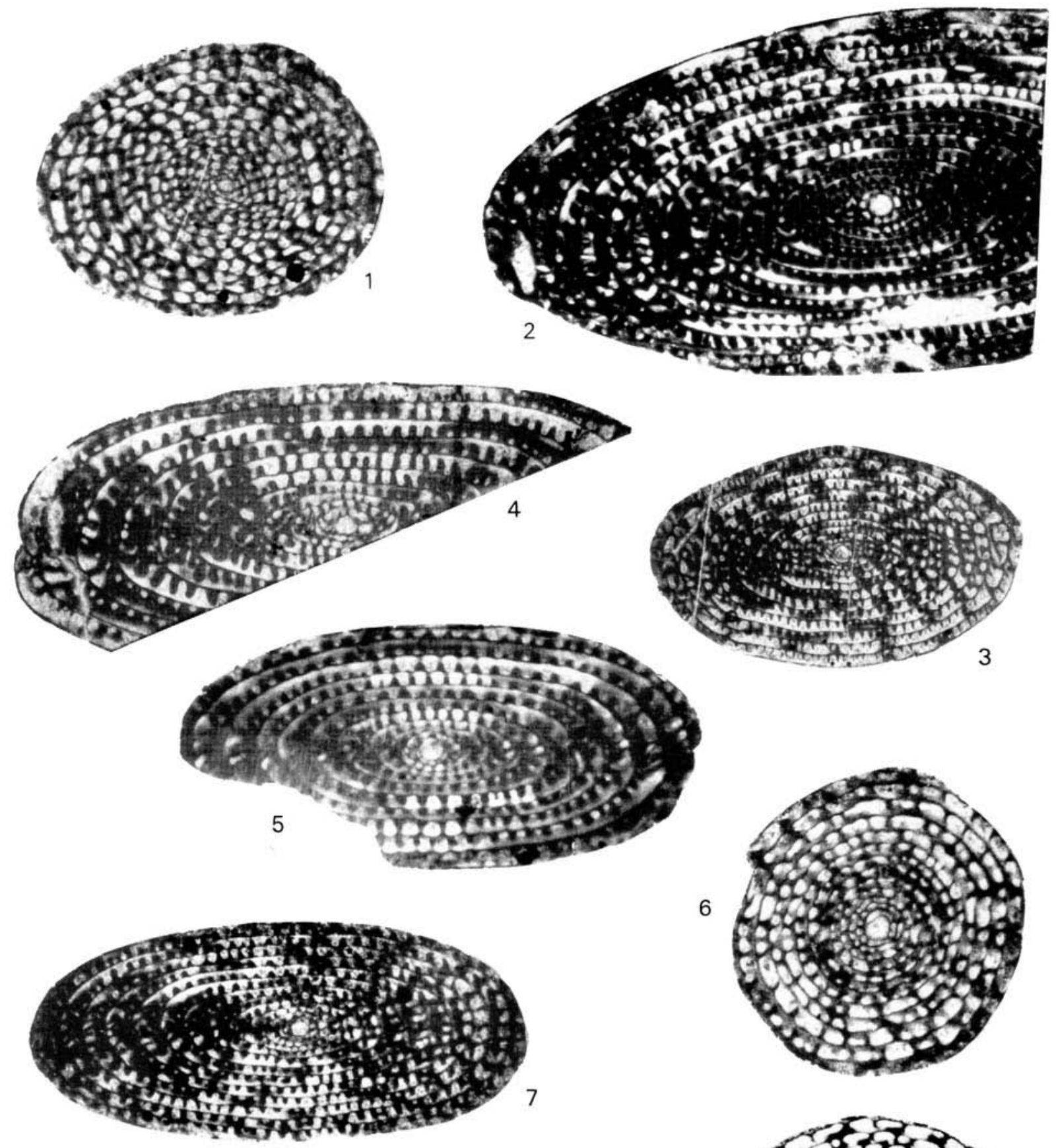

6
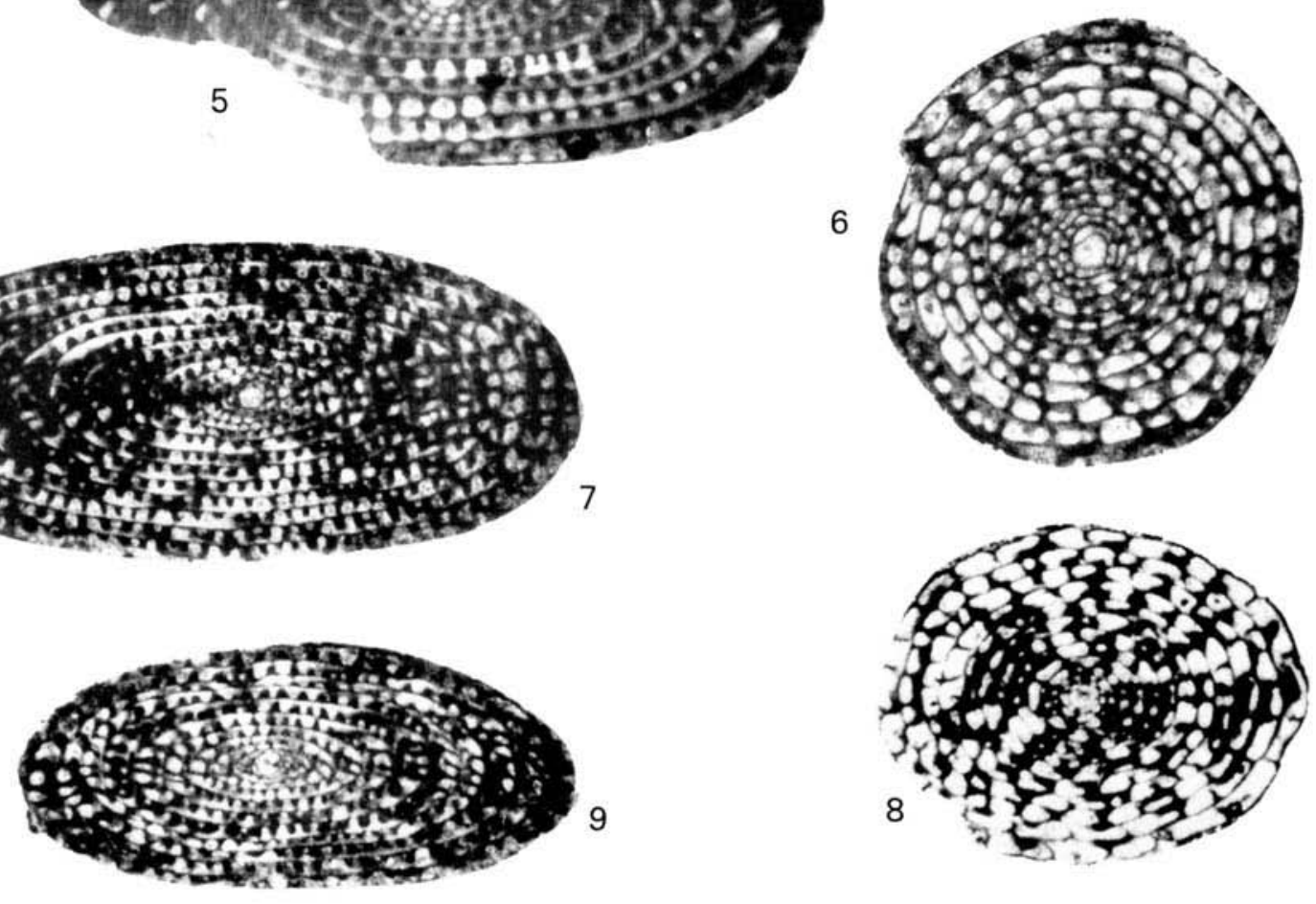
the lower part of this facies, is a significant horizon for correlation with Facies 3 and 4 . The same fusuline assemblage and crushed specimens of Verbeekina also reappear in Facies 6, which is considered to be contemporaneous with Facies 5. Representative fusuline assemblages of Facies 5 are given in Fig. 4.

Facies 6: Dolomitised algal mats: Intertidal-supratidal flats (late Murgabian-Early Midian).

This facies is $69 \mathrm{~m}$ thick and outcrops in small hills to the south of $\mathrm{Km} 7$, near a quarry with red shale. The limestones are thick bedded bioclastic and peloidal wacke/packstones with bedding striking $280^{\circ}$ and dipping $40^{\circ}-50^{\circ}$ to the west. The top of the hills comprise red siliceous shale beds which cap the underlying Facies 6. The lower and upper part of this facies contains $0.5 \mathrm{~m}$ of laminated algal dolomite, containing abundant bird's eye structures and algal filaments. In the middle part of the facies, the limestones comprise bioclastic peloidal wackestones and packstones. Verbeekinid foraminifera dominate this part of the section. Verbeekina verbeeki (Geinitz), Pseudodoliolina pseudolepida (Deprat), Afghanella schencki Thompson and $A$. sumatrinaeformis (Gübler) are common whilst advanced species of Parafusulina occur sparingly throughout the facies. $V$. verbeeki becomes more abundant towards the top, together with Metadoliolina and Colania. Globivalvulina also appears towards the top of this facies. Verbeekina occurs in packstones associated with Pseudodoliolina and shows signs of crushing during compaction (as noted in Facies 5, above). This horizon can probably be correlated with the similar horizon of crushed Verbeekina described by Toriyama (1978) from the Khao Khao section.

The faunal assemblage of Verbeekina verbeekiPseudodoliolina-Metadoliolina of Facies 6 is similar to that of Facies 5 and belongs to the Neoschwagerina Zone, probably the $N$. craticulifera- $N$. margaritae zones (late Murgabian). The presence of Metadoliolina lepida (Schwager), Colania douvillei (Ozawa) and Globivalvulina suggests that the top of this facies may extend into the lower part of the Yabeina Zone, early Midian (Late Permian).

\section{DISCUSSION}

The Permian carbonates in this area can be divided into six major carbonate facies, from north to south, namely: slope- turbidites, platform margin algal reef, back-reef, open marine interior platform, protected shelf and intertidalsupratidal (peritidal) environments. The younger beds indicate progressively shallower environments, suggesting that the Saraburi section represents a regressive Early to Late Permian sequence. Unfortunately, the outcrops are not large enough to postulate oceanward and basinward directions or the possible direction of progradation associated with this regressive sequence. Diagenetic fabrics suggest that the limestones have undergone early and subaerial diagenesis as well as subsequent subsurface diagenesis. The sections range in age from Sakmarian (Early Permian) to early Midian (Late Permian) in age. The evidence of a disconformity between Facies 2 and Facies 3 and 5 during the early Mid-Permian (Figs. 2 and 6) is supported by diagenetic and palaeontological criteria, which are discussed later in this paper.

\section{FUSULINE ASSEMBLAGE ZONES}

There have been several previous studies of the fusuline foraminifera from Thailand and Malaysia. In the "Carboniferous and Permian systems in Thailand and Malaysia" Toriyama et al. (1975) compiled a list of 197 species of fusulines belonging to 50 genera and subgenera. Ingavat et al. (1980) and Toriyama (1984) summarised the fusuline zonation and characteristics of the Ratburi Limestone in Thailand and its equivalents in Malaysia, in which 265 species belonging to 70 genera were described. The fusuline fauna from Khao Phlong Phrab, Khao Khao, and Khao Imot, Saraburi, west of my study area (Fig. 1), have been described in detail by Pitakpaivan (1965), Ozawa (1970b), Toriyama (1976; 1978), Toriyama \& Kanmera (1977; 1979) and Toriyama \& Pitakpaivan (1973). Consequently, taxonomy will be omitted in this paper. The dasycladacean algae from Khao Phlong Phrab and Khao Khao have been described by Endo (1969) and the identification of the algae in the present article is based on his descriptions.

The three-fold division of the Permian, based on the Permian Tethys scale for the Mediterranean-Alpine fold belt was revised by Leven (1981) and is now widely accepted by workers in Southeast Asia (Toriyama et al., 1975; Ingavat al. 1980; Toriyama, 1984; Ingavat, 1984; Ingavat-Helmcke \& Helmcke, 1986; Fontain et al., 1986). Correlation of fusuline assemblages of overlapping facies, such as these, is best

Figs 1-6 Pseudoreichelina sp. Figs.1,2, tangential sections. Thin sections T.275a,c; Figs 3,4, tangential sections. Thin sections T.275b,d; Fig.5,6, axial and parallel section. Thin sections T.267a,b. All from Facies 2. Sakmarian-Yahtashian, Early Permian.

Figs 7-9 "Pseudoendothyra" sp. Axial sections. Thin sections T.252a,b, T.254. Facies 2. Sakmarian-Bolorian (Early-early Mid-Permian).

Figs 10-12, Hemigordius sp. Various sections. Thin sections T.518a,b, T.520. Facies 3. 15,16 Murgabian (Middle Permian).

Figs 13,14 Neodiscus sp. Two views. Thin section T.4522. Facies 3. Middle Permian.

Fig.17 Tetrataxis sp. Edge view. Thin section T.403. Facies 3. Middle Permian.

Figs 18-20 Pachyphloia sp. Three views. Thin sections T.311 and T.415. Facies 3 and 5, respectively. Middle Permian

Fig.21 Lunucammina sp. Longitudinal section. Thin section T.315. Facies 5. Middle Permian. 

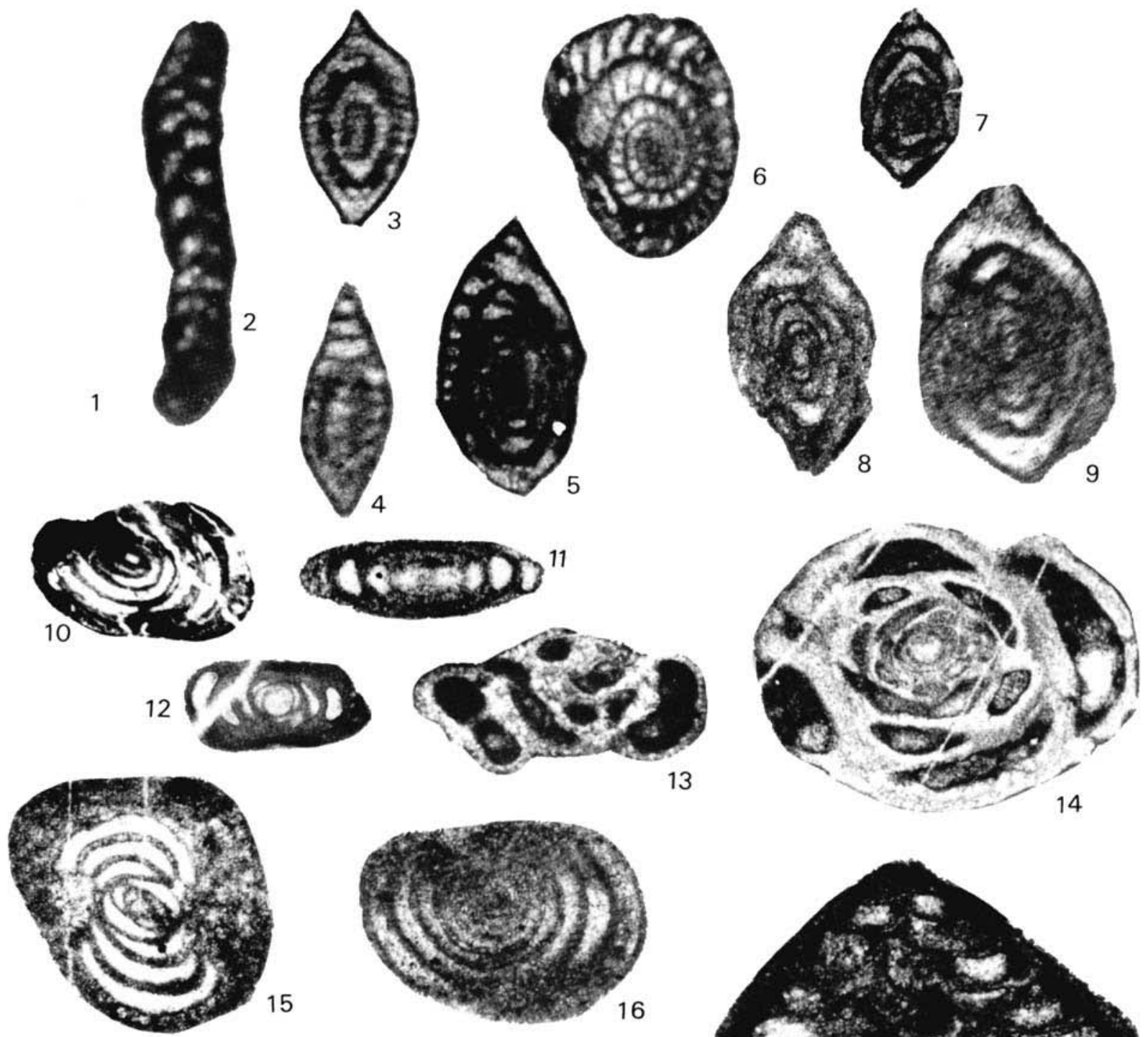

13
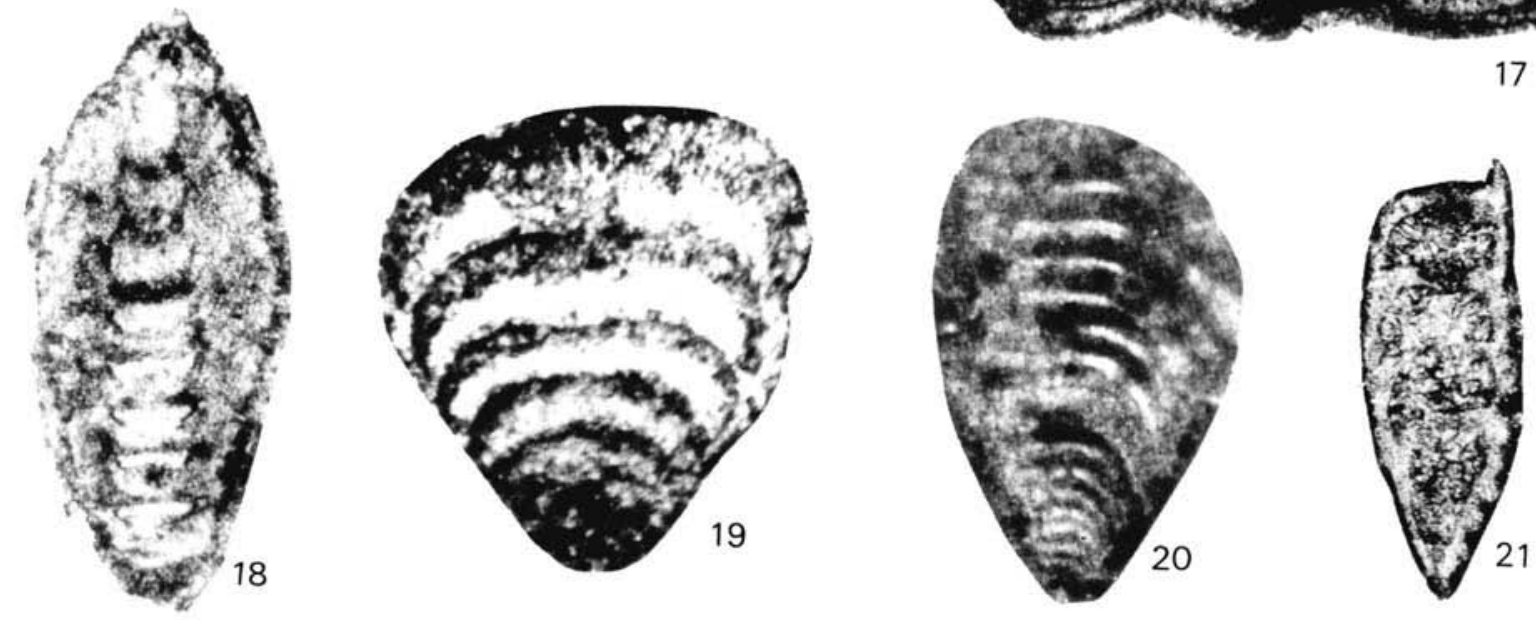


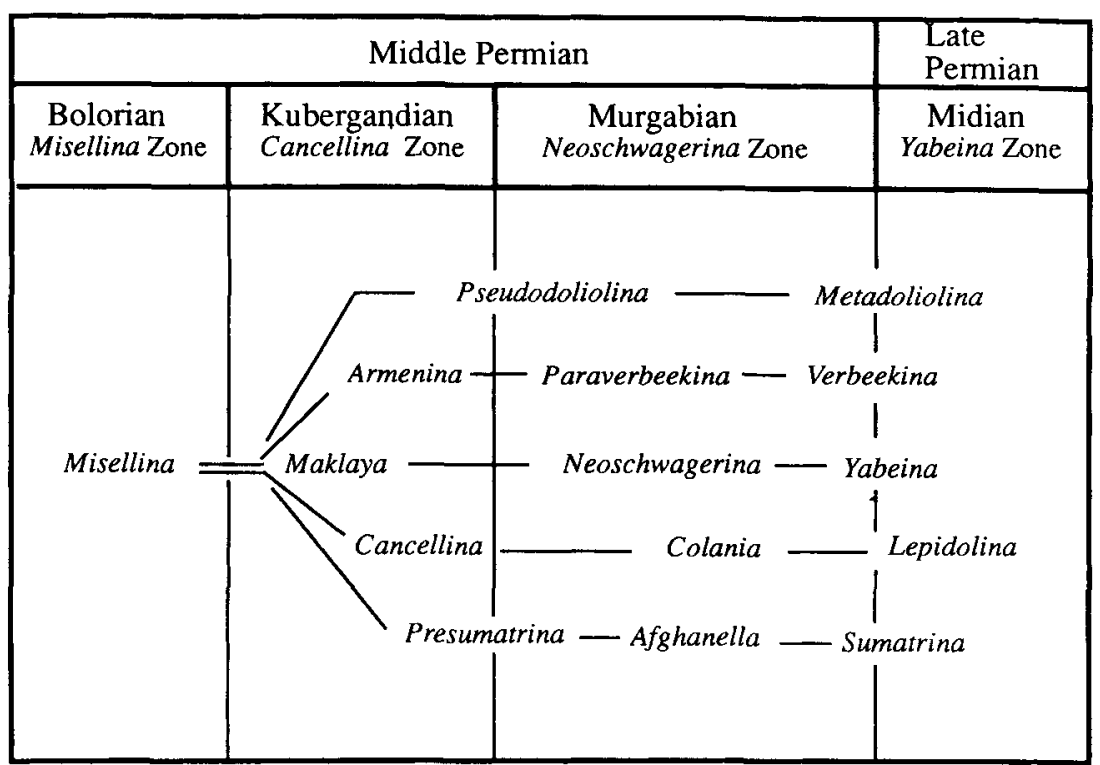

Fig. 5 The evolution of verbeekinoidean bioseries lineages during the Middle and Upper Permian (after Ozawa, 1970a).

achieved by using the stage of phylogenetic evolution and extinction of the mid-Permian Verbeekinoidea, as already demonstrated by Ozawa (1970a), Kanmera et al. (1976), Toriyama et al. (1978), Ingavat et al. (1980),Ingavat-Helmcke \& Helmcke (1986) and Ingavat (1988).

The Tethyan Verbeekinoidea evolved independently from primitive species of Misellina into five bioseries in the early Middle Permian (Bolorian) (Fig.5). The evolutionary trends of the verbeekinoidean foraminifera are characterised by the modification and reduction of the keriothecal layer, increased development of the parachomata, multiplication of septa and septula, and enlargement of the test (Kanmera et al., 1976; Ozawa, 1970a; Ross, 1979).

Eight fusuline zones are proposed as an aid to correlating the Saraburi section (Fig.6). The age ranges of the individual species found in Facies 1-6 are shown in Fig. 4.

\section{Robustoschwagerina-Nagatoella Zone}

(Thickness 8m; lower part of Facies 2).

This zone forms the base of Facies 2 in the lowest part of the section and is characterised by an abundance of Robustoschwagerina (Pl.1, figs 1-3) and Nagatoella (Pl. 1, figs 4-7). The fusuline genera Toriyamaia, Pseudofusulina, Pseudoendothyra and Pseudoreichelina, together with the dasycladacean algae Vermiporella and Anthracoporella are also common in this assemblage zone. The Robustoschwagerina species from Saraburi are extremely large (10-12 $\mathrm{mm}$ in diameter), and have a spherical test with deep umbilici (Pl. 1, figs 1-3) which readily distinguishes them from other schwagerinids. This assemblage of Robustoschwagerina-Nagatoella-Toriyamaia I have assigned to the Sakmarian stage of the Early Permian. It compares closely with the assemblages from the Robustoschwagerina Nagatoella Zone from west Japan (Kanmera \& Mikami, 1965) and the Robustoschwagerina Zone from west Kampuchea (Toriyama, 1976; Fontaine et al., 1986) dated as Sakmarian (Early Permian). Previously, Robustoschwagerina tumida (Licharev) was recorded from isolated hills from the north and northwest of Thailand, near Chiangmai and Phrae (Toriyama, 1944) but it was associated with Triticites ozawai Toriyama, Pseudoschwagerina yanagidai (Igo) and Pseudoschwagerina mouonthensis (Deprat) and was referred by Igo (1972) to the (older) Pseudoschwagerina Zone of the Asselian (Early Permian). The Sakmarian index fauna appears to be absent, especially in the central part of Thailand (Toriyama, 1976; Ingavat et al., 1980; Fontaine et al., $1986)$, although Ingavat $(1984 ; 1988)$ has proposed a zone of Robustoschwagerina tumida for the Sakmarian, based on specimens reported from the north of Thailand, as mentioned above. My Saraburi species of Robustoschwagerina occurs with an associated fauna (Nagatoella and Toriyamaia), which indicates it must be younger than the Pseudoschwagerina Zone; it is probably a derivative of $R$. tumida and for this reason is kept in open nomenclature.

Sakmarian fusuline faunas have been reported from various localities in Thailand by recent workers, but none of the index fauna of the Sakmarian-Yahtashian stages has been reported from continuous sections from central Thailand, until now. If this is supported by subsequent work it would provide the answer to the question set by Toriyama et al. (1975) as to whether the latest part of the Early Permian is missing in central Thailand or has just not been found. The Robustoschwagerina-Nagatoella Assemblage

\section{Explanation of Plate 8}

Fig. 1 Palaeotextularia sp. Thin section T.256. Facies 2. Early Permian. x40.

Fig. 2 Cribrogenerina cf. sumatrina (Lange). Thin section T.235. Facies 2. Middle Permian. $\times 25$.

Figs 3,5,8 Climacammina cf. tudiola (Lange). Thin sections T.312, 235. Facies 2 and 5 respectively. Bolorian-Murgabian, Middle Permian. $x 25$.

Figs 4,9 Deckerella sp. Thin sections T.270a,c. Facies 2. Bolorian, early Mid-Permian. x25.

Fig. 6 Globivalvulina sp. Thin section T.718. Facies 6. Early Midian, Late Permian $x 40$.

Figs 7,10,11 Geinitzina sp. Thin sections T.311, 520, 415. Facies 3 and 5. Late Murgabian, Middle Permian. x50 (Fig.7; x15 Figs 10,11).

Figs 12,13 Bradyina? sp. Thin sections T.714a,b. Facies 6. Early Midian, Late Permian. $x 50$.

Figs 14,15 Pachyphloia sp. Thin sections T.328a, 321. Facies 5. Murgabian, Middle Permian. x50. 

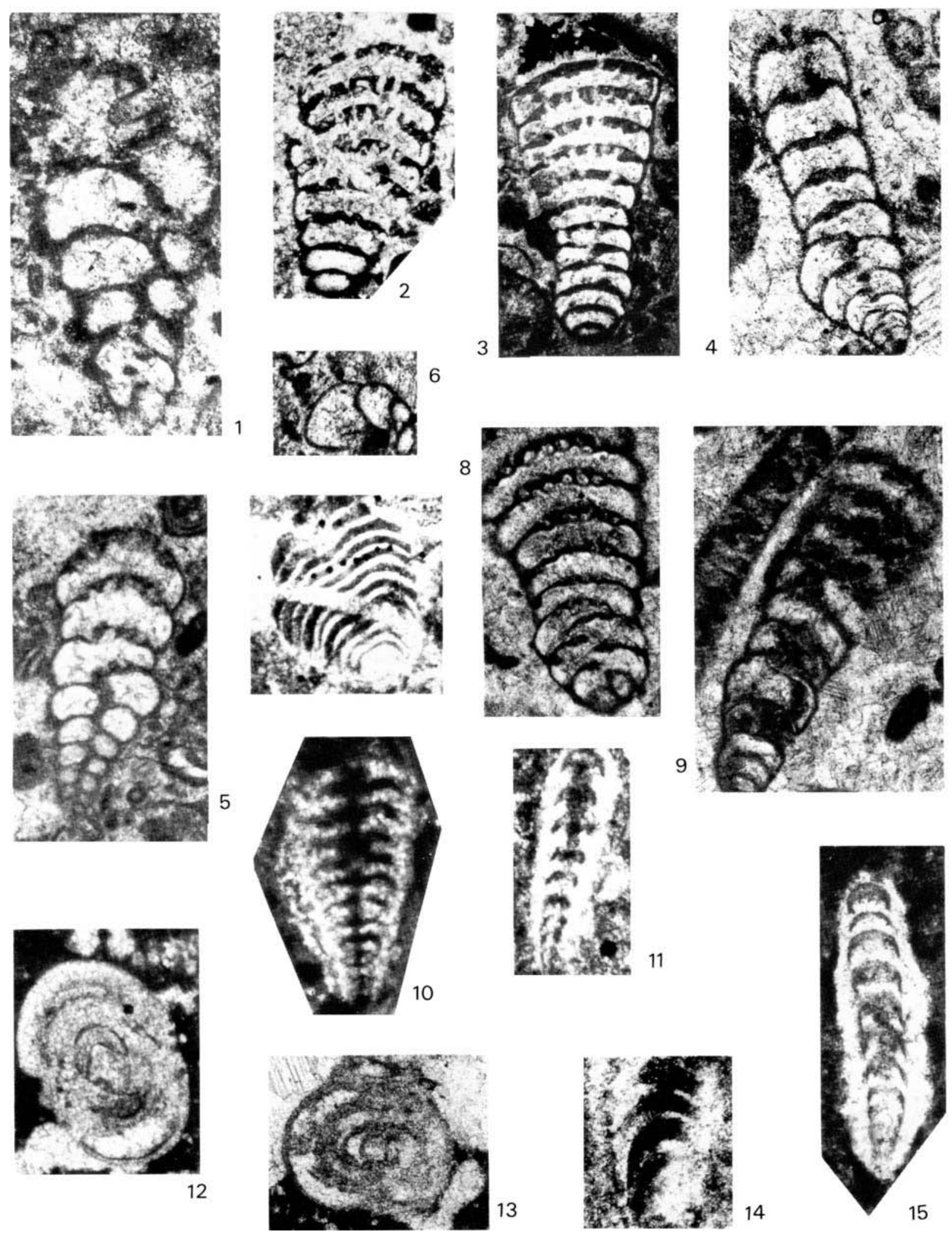
Zone, it is hoped, can now be used as the standard for the correlation of Sakmarian carbonates in Thailand.

Above this zone lie Archaeolithoporella-Tubiphytes beds which occur as algal buildups $25 \mathrm{~m}$ thick. Overlying these, in turn, are algal-fusuline limestones of Artinskian/Yahtashian age (see below).

\section{Pseudofusulina vulgaris-Chalaroschwagerina Zone.}

(Thickness 125m; Facies 1 and 2).

In this zone schwagerinids, schubertellids, staffellids and other small fusulines are prolific (Pl. 2, figs 1-15), in association with dasycladacean algae, encrusting algae, calcisponge and crinoidal fragments. Pseudofusulina vulgaris (Schellwien), P. padangensis (Gübler), and species of Darvasites, Chalaroschwagerina and Cuniculinella occur moşt commonly throughout the zone, whilst the NagatoellaToriyamaia assemblage is still prevalent in the lower part. The genera Schubertella, Mesoschubertella, Neofusulinella, Minojapanella, Nankinella, Ozawainella, Pseudoreichelina and

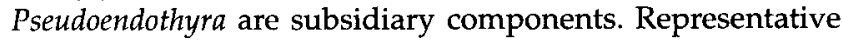
species of Misellina appear towards the top of the zone while dasyclad algae (Vermiporella, Clavaporella, Gyroporella, Mizzia and Anthracoporella) and smaller foraminifera such as Palaeotextularia, Cribrogenerina and Climacammina are also common.

Advanced species of Pseudofusulina, and primitive species of Parafusulina, appear in this zone and become common through the rest of Facies 2. Pseudofusulina vulgaris (Schellwien) has a close affinity with Cuniculinella globosa (Skinner \& Wilde), as noted by Igo et al. (1979). The faunal assemblage of this zone can be placed within the Yahtashian Stage, or the early Artinskian (late Early Permian). This association of Pseudofusulina vulgaris, P. padangensis, Cuniculinella, Nagatoella, Minojapanella and Toriyamaia is closely comparable with the fauna found by Igo et al. (1979) from the Sungei Sedili area, Johore, Malaysia. They described 26 species and in correlating the assemblage with that of the Pamir, South China and Japan, considered it to be older than the fauna of the Ratburi Limestone from the Khao Phlong Phrab section (Misellina Zone). My P. vulgarisChalaroschwagerina Zone can also be considered coeval with the Monodiexodina shiptoni Zone designated by Ingavat \& Douglass (1981) from Mae Sariang in the north of Thailand.

The occurrence of Pseudofusulina species, together with the associated schwagerinids, declines towards the top of the facies, in parallel with the increasing numbers of primitive members of the verbeekinoidean group, Misellina, Armenina and Brevaxina.

Facies 1, although more restricted in thickness, has a faunal association essentially the same as the later part of Facies 2, and can probably be placed within the $P$. vulgarisChalaroschwagerina Zone, Yahtashian Stage of the Early Permian (D. Vachard, pers. comm.).

\section{Armenina-Misellina confragaspira-Misellina otai Zone}

(Thickness 260m; upper part of Facies 2).

The zone overlies the Pseudofusulina vulgarisChalaroschwagerina Zone and the ArchaeolithoporellaTubiphytes buildups. In it, the declining populations of Pseudofusulina parallel the increasing number of species of Misellina, Armenina and Parafusulina. The base of the zone marks the first appearance of $M$. otai Sakagushi \& Sugami; from the middle part of this zone it becomes common, whilst $M$. confragaspira (Leven), $M$. ovalis (Deprat) and $M$. claudiae (Deprat) first appear and become common towards the top. Brevaxina and Armenina species also first appear towards the top of the zone (see Pl. 2).

These assemblages occur in association with advanced schwagerinids, together with species of Schubertella, Mesoschubertella, Neofusulinella, Minojapanella, Ozawainella, Nankinella, Sphaerulina and Pseudoreichelina. A few specimens of Neothailandia, Maklaya and Pseudodoliolina, which also occur in the Misellina and Maklaya zones in the Khao Phrong Phrab sections (Toriyama et al., 1974), appear towards the top of this zone. The fusuline assemblages occur in association with abundant dasyclad algae, encrusting algae, and smaller foraminifera.

My Armenina-Misellina otai- $M$, confragaspira assemblage zone can be placed within the Misellina Zone, Bolorian (early Middle Permian) of world correlation. It is also considered coeval with the $M$. otai-M. termieri and $M$. ovalis$M$. confragaspira zones of the Khao Phlong Phrab section, Saraburi (Toriyama et al., 1974 and Ingavat et al., 1980) (see Fig. 6).

In contrast to the exposures of this zone of Facies 2, which occur as karstic limestone pavements, the outcrop of Facies 5 rises abruptly to form a small hill (Fig. 2). The boundaries between Facies 2, 3 and 5 are obscured, but are probably disconformable and subsequently faulted. The faunal assemblage of Facies 5 appears to represent a higher

\title{
Explanation of Plate 9
}

\author{
All figures $\times 10$, except where stated.
}

Fig. 1 Anthracoporella spectabilis Endo. Oblique longitudinal sections. Thin section T.268d. Facies 2, open shelf transition zone. Early Permian. Fig. 2 Nagatoella sp. and Anthracoporella spectabilis Endo, encrusted by Tubiphytes within a fibrous cement. Facies 2, platform margin algal buildup. Sakmarian, Early Permian.

Fig. 3 Gyroporella sp. Longitudinal section. Thin section T.275d. Facies 2, open shelf platform margin transition zone. Early Permian.

Figs 4,5,7 Clavaporella cf. facetae Endo. Various sections. Thin sections T.227c, 220c. Upper part of Facies 2, transition zone. Yahtashian-Bolorian, late Early Permian-early Mid-Permian. Fig.4, x20.

Fig. 6 Gymnocodiscese sp. (cup form)Thin section T.270f. Facies 2, back reef and transition zone. Bolorian, early Mid-Permian. x30. Fig. 8 Likanella sp. Side view. Thin section T.235d. Facies 2. Bolorian. x25.

Figs 9,10 Mizzia sp. Side and longitudinal vies. Thin sections T.221b, c. Facies 2, platform margin transition zone. Early Permian. 

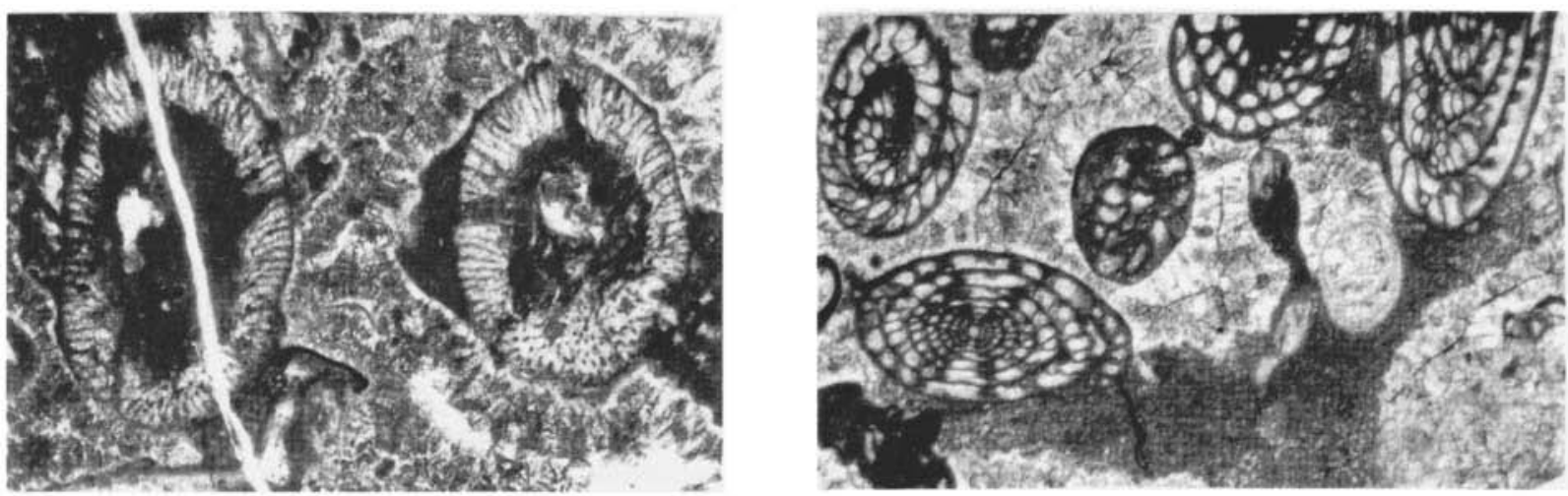

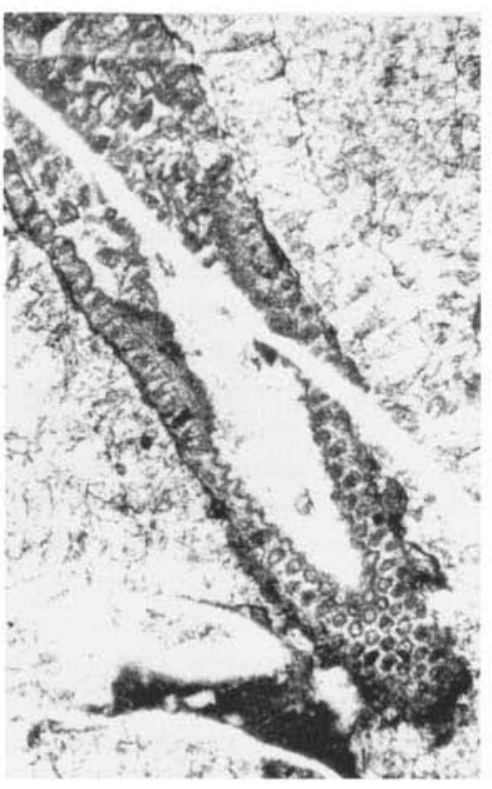

3
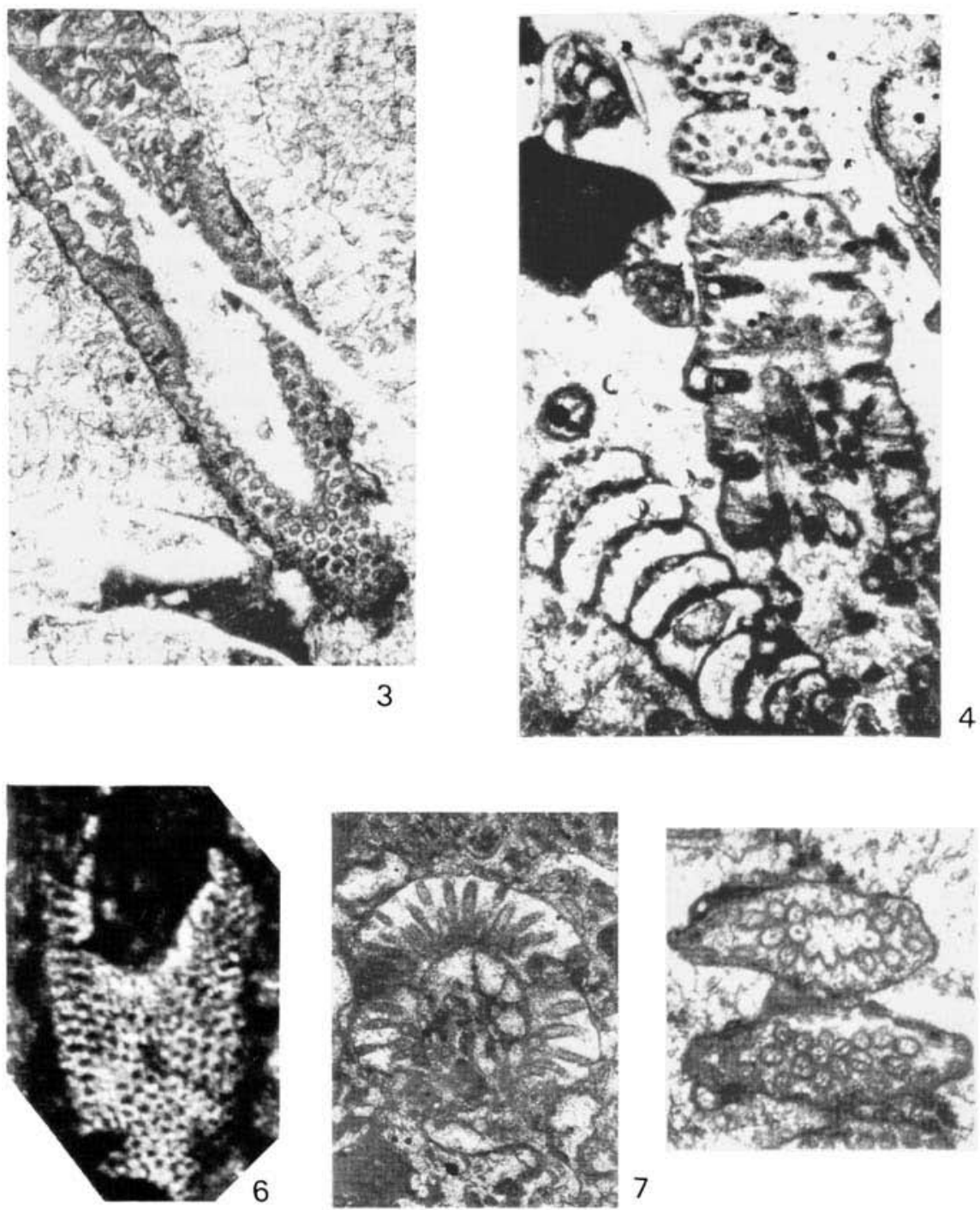
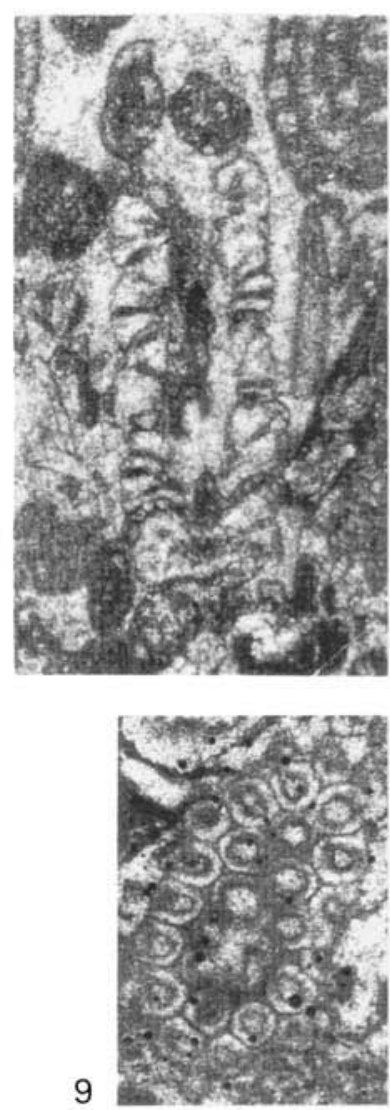

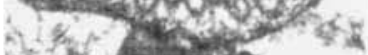

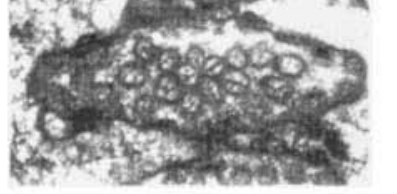

10 
stratigraphic horizon than that in Facies 3, but is equivalent in age to that of Facies 6 (see Figs 4 and 6). A brecciated limestone with a reddish matrix occurs at the base of Facies 3, which contains a Misellina, Nankinella and Armenina Facies 2 fauna in the limestone clasts. The fauna in Facies 3 and 4 seems to have no direct association or lineage continuity with that in Facies 2. Although the age ranges of the fusulines do not show a significant time gap, the sudden change of the faunal assemblages and the absence of the Misellina bioseries lineages, Maklaya, Cancellina and Armenina (Fig. 5) indicate an abrupt change in environment, unfavourable for the verbeekinoidean evolution and their particular ecological niche. This may correspond with the abrupt marine regression during the late Early Permian and early Middle Permian, postulated by Vail et al. (1977) (See Fig. 6). Ingavat-Helmcke \& Helmcke (1986) and Ingavat (1988) suggest that this may correspond to the Ural Orogeny.

\section{Parafusulina-Paraverbeekina-Chusenella}

Zone (Thickness 50-65m; lower parts of Facies 3-5).

Intermediate and advanced species of Parafusulina and Chusenella are abundant and occur together with Verbeekina (Paraverbeekina) and Afghanella, forming significant assemblages for correlation throughout the zone.

Faunal characteristics allow this zone to be divided into two assemblages: Parafusulina (gigantea)-ChusenellaPseudodoliolina (ozawai) and Verbeekina (Paraverbeekina)Chusenella-Pseudodoliolina. Verbeekina and Parafusulina do not occur together in this assemblage. Pseudodoliolina ozawai Yabe \& Hanzawa is common in Facies 5 while Afghanella megaspherica (Sheng) and Neoschwagerina simplex Ozawa are common in Facies 3 and 4 . The genera Maklaya, Neothailandia, Presumatrina and Yanchienia are also present in Facies 3.

This zone, although it lacks the endemic index species of Maklaya and Cancellina of the Kubergandian stage can, however, be correlated with the Maklaya zones of the Khao Phlong Phrab section (Fig. 6), by reference to the flourishing assemblage of Parafusulina-Chusenella and their allies, and is assignable to the Cancellina Zone, Middle Permian, of Tethyan terminology (Toriyama et al., 1974; Ingavat et al., 1980 and Ingavat, 1984).

The absence of endemic species of Maklaya and Neothailandia, which are otherwise abundant in the Khao Phlong Phrab section, is of ecological and stratigraphical significance. Maklaya, Cancellina and Armenina are derived directly from Misellina (Fig. 5), which occurs in abundance in the zone below (in Facies 2), as mentioned previously. Their absence suggests that the environment changed unfavourably for the verbeekinoidean fusulines in this area during Bolorian-Kubergandian times. In the Khao Phlong Phrab area, only $7 \mathrm{~km}$ to the west, the verbeeknid bioseries seems to have flourished without disruption from the Misellina phase into the Neoschwagerina simplex phase (early Murgabian), then there is an unconformity (Toriyama et al., 1974). In our area, this appears to be earlier and would seem to mark the onset of a regression during late Early Permian (Vail et al., 1977, see also Fig. 6) which corresponds with the Ural Orogeny and the beginning of tectonic activity in the Phetchabun Belt in the northeast (Helmcke et al., 1985, Ingavat-Helmcke \& Helmcke, 1986).

5. Neoschwagerina simplex-Afghanella megaspherica Zone. (Thickness 38m; Facies 3-5).

This zone covers the middle part of Facies 3 and 4 and the lower part of Facies 5. The fusuline assemblages now change considerably. The limestones in Facies 3 and 4 have a dominant assemblage of Neoschwagerina-ParafusulinaAfghanella, while the limestones and interbedded shales of Facies 5 contain a dominant assemblage of PseudodoliolinaVerbeekina-Afghanella. Although Parafusulina and Verbeekina are common to these two biofacies, the former genus seems to decrease in importance, while the latter becomes increasingly dominant towards the top of the zone.

In more detail, Afghanella megaspherica Sheng, Verbeekina verbeeki (Geinitz) and Parafusulina gigantea (Deprat) are species common to both these biofacies. Parafusulina kaerimizensis (Ozawa) and P. japonica (Ozawa) disappear towards the top of the zone. Pseudodoliolina ozawai Yabe \& Hanzawa, P. pseudolepida (Deprat) and species of Chusenella are abundant in Facies 5, whilst Afghanella megaspherica Sheng, Parafusulina kaerimizensis (Ozawa), P. gigantea (Deprat) and Chusenella spp. are common in Facies 3 and 4. Neoschwagerina simplex Ozawa is common only in lower parts of Facies 3 and 4, with primitive species of Pseudodoliolina, for example $P$. cf. saraburiensis (Toriyama \& Kanmera) and P. ozawai Yabe \& Hanzawa. Several species of Presumatrina also appear in this zone. Many of these species are figured in Plates 3-7.

The faunal assemblages of this zone have the same stratigraphic age range as the Neoschwagerina simplex Zone and the lowest part of the Presumatrina schellwieni Zone in the upper part of the Khao Phlong Phrab section (Toriyama et al., 1974), and with the lowest part of the Khao Khao section (Toriyama \& Kanmera, 1979) (see Fig. 6). Ingavat et al. (1980) correlated these zones with the Neoschwagerina simplex Zone of Afghanistan and southeast Pamir, belonging to the early part of the Murgabian stage of the Middle Permian, in worldwide correlation.

\section{Neoschwagerina craticulifera-Afghanella pesuliensis-} Pseudodoliolina pseudolepida Zone

(Thickness 36-38m; Facies 3-6).

This zone occupies the upper part of Facies 3 and 4, middle part of Facies 5 and the lower part of Facies 6 . In Facies 5, although the limestones of the protected lagoon are interrupted by intertidal deposits, the PseudodoliolinaAfghanella-Verbeekina assemblage still flourished, remarkably right through to the top of the zone. Neoschwagerina-Afghanella-Parafusulina on the other hand, still dominate Facies 3 and 4 . The schwagerinids decline in the latter assemblage, while the verbeekinid group flourish in the former. Pseudodoliolina pseudolepida (Deprat), Afghanella pesuliensis (Ozawa \& Tobler), Verbeekina verbeeki 
Fusiline biostratigraphy of the Permian pf Central Thailand

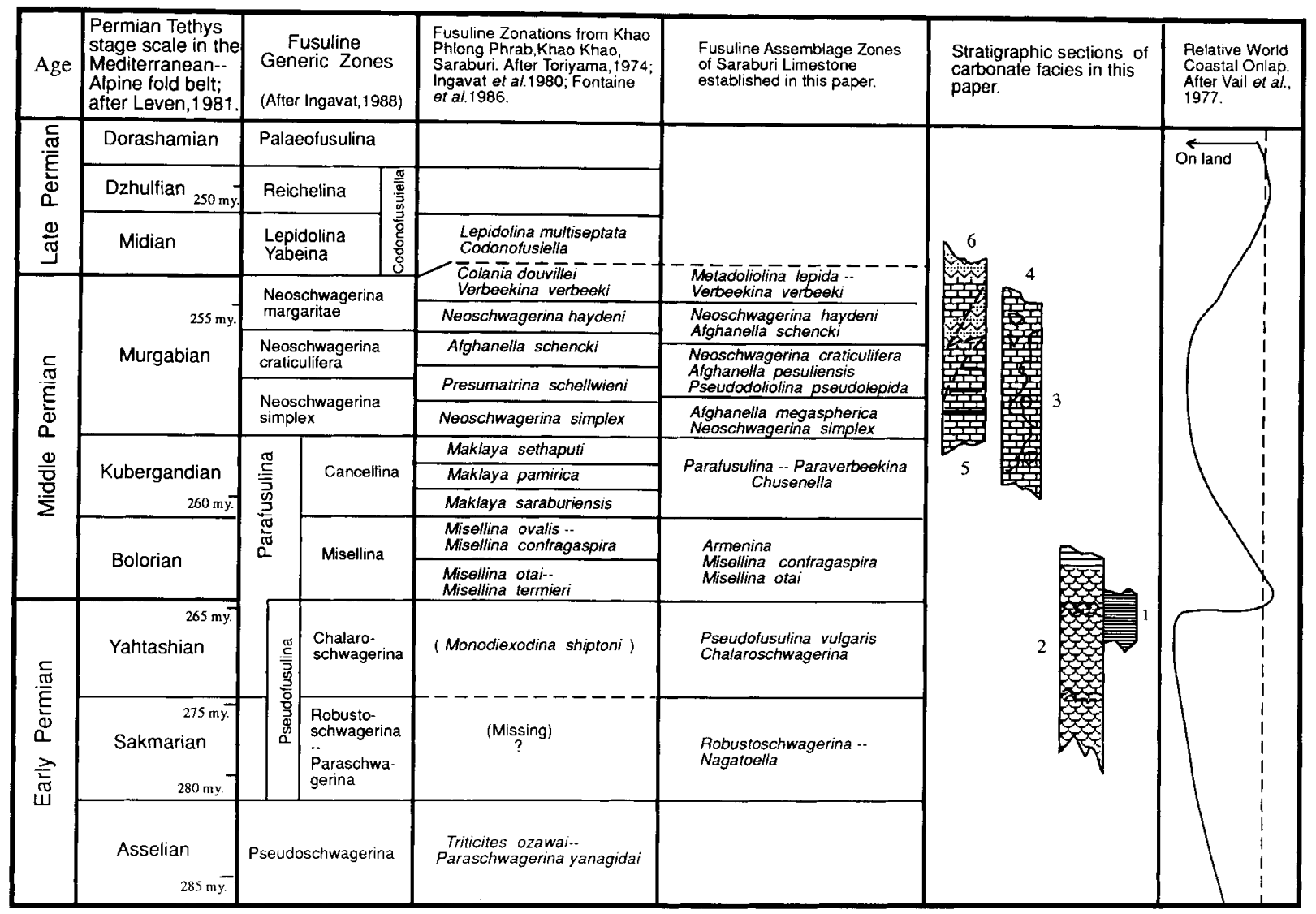

Key :

Turbidites, microcrystalline limestone; slope.
Archaeolithoporella-Tubiphytes buildups; platform margin.
$\begin{aligned} & \text { Coral-bryozoan fusuline packstones \& } \\ & \text { boundstones; back reef interior platform. }\end{aligned}$
Wacke/packstones and dolomitised algal mats;
peritidal flats inner shelf.

Dolomitised grainstones/boundstones; platform margin.

Fig. 6 Fusuline assemblage zones showing correlations with Khao Phlong Phrab and Khao Khao zonations. Note the absence of Maklaya species zones in the Kubergandian of the study area, which coincides with the discontinuities between Facies 2 and $3 / 5$ and the marine regression.

(Geinitz) and $V$. pontica (Miklukho-Miklay) are the most common species in Facies 5 and the lower part of Facies 6, in association with Parafusulina gigantea (Deprat). Metadoliolina cf. pinguis (Toriyama \& Kanmera) first appears in Facies 5 and 6. Chusenella spp. are still common in this zone. In Facies 3 and 4, Neoschwagerina craticulifera (Schwager), Afghanella pesuliensis (Ozawa \& Tobler), A. schencki Thompson and Parafusulina gigantea (Deprat) and its allies are also common; $A$. schencki Thompson becomes more prolific towards the top of the zone, together with the appearance of advanced species of Neoschwagerina and Colania. Dasycladacean algae and calcisponges are common in the bioherms whilst smaller foraminifera are also common to all the biofacies of this zone. For instance,
Hemigordius and Climacammina are abundant in the upper part of Facies 3. Tetrataxis, Agathammina, Neodiscus, Pachyphloia, Cribrogenerina and Geinitzina are common throughout.

The assemblages in this zone resemble those described from the Presumatrina schellwieni Zone of the upper part of Khao Phlong Phrab and lowest part of Khao Khao sections (Toriyama et al., 1974; Toriyama \& Kanmera, 1979); their distribution would also probably range high into the Afghanella schencki Zone of those sections. A comparison with similar faunas in Japan, the Pamirs, southern China, Afghanistan and Cambodia, places my $N$. craticulifera- $A$. pesuliensis-P. pseudolepida Zone within the upper part of the Neoschwagerina simplex and lower and middle part of the $N$. 
craticulifera zones of the mid Murgabian (Middle Permian), in terms of world correlation.

7. Neoschwagerina haydeni-Afghanella schencki Zone

(Thickness 15-30m; upper parts of Facies 4-6).

This zone is characterized by a gradual change of fusuline assemblages but no abrupt change of bio-lithofacies. Species of Neoschwagerina and Afghanella schencki Thompson dominate the assemblage in Facies 4, whilst Pseudodoliolina pseudolepida (Deprat) and A. schencki dominate in Facies 5 and 6.

Afghanella schencki Thompson occurs abundantly throughout the zone; this species, together with Pseudodoliolina pseudolepida (Deprat) have long ranges, more or less throughout the Murgabian (Toriyama \& Kanmera, 1979). P. pseudolepida and Neoschwagerina simplex Ozawa occur together with Verbeekina verbeeki (Geinitz) in Facies 6. Afghanella sumatrinaeformis (Gübler), the advanced member of the Afghanella (megaspherica-pesuliensis-schenckisumatrinaeformis) bioseries appears towards the top of this zone in Facies 5 \& 6. Parafusulina gigantea (Deprat) still occurs in the lower part of the zone while Chusenella finally dies out. Metadoliolina cf. lepida (Schwager) and $M$. multiseptata (Ozawa) appear towards the top.

In this zone, Neoschwagerina is represented by advanced members of the simplex-craticulifera-margaritae bioseries. $N$. cf. haydeni (Doutkevitch \& Khabkov), which is considered to be a subspecies of $N$. craticulifera (Deprat), and N. cheni Sheng, an advanced member of the $N$. margaritae phase (Toriyama \& Kanmera, 1979), appear towards the top of the zone. Colania also occurs in the upper part of the zone in Facies 4 . The faunal assemblages allow a correlation with the upper part of the A. schencki and the $N$. haydeni zones in the Khao Khao section (Fig. 6), corresponding, in the most part, to the $N$. maragaritae Zone, late Murgabian, of world correlation (Ingavat et al., 1980).

\section{Metadoliolina lepida-Verbeekina verbeeki Zone}

(Thickness 4m; uppermost part of Facies 6).

This assemblage dominates the upper part of Facies 6 over a narrow interval. Pseudodoliolina becomes rare, Metadoliolina cf. lepida (Schwager) and Verbeekina verbeeki (Geinitz) more common, the shells of the latter at one horizon being so crowded together so as to form a Verbeekina-bed. The smaller foraminifera Bradyina and Globivalvulina occur in dolomitised algal mats above the Verbeekina horizon. A correlation can be made with a similar horizon of crowded Verbeekina in the $V$. verbeeki Zone at Khao Imot (Fig. 1), west of the present area, described by Ozawa (1970b). There, it occurs together with Colania donvillei (Ozawa). Ozawa (1970b) established the V. verbeeki Zone within the upper part of the Neoschwagerina margaritae Zone, of world correlation, higher than the $N$. haydeni Zone of the Khao Khao section. It seems that the different assemblages from these two localities were controlled largely by differences in environment. Metadoliolina lepida and Colania douvillei are both advanced members of their bioseries, Pseudodoliolina-Metadoliolina and Cancellina-
Colania-Lepidolina, respectively (see Fig. 5), which occur in the Late Murgabian-Early Midian stages (Middle-Late Permian). Furthermore, the assemblage of MetadoliolinaVerbeekina-Globivalvulina, right at the top of my section, can be correlated with those occurring in the Lepidolina multiseptata Zone at Srakeow, Prachinburi, which is considered to belong to the earliest part of Midian by Pitakpaivan \& Ingavat (1980) (= Yabeina Zone of world correlation (Fig 6).

Above the $M$. lepida- $V$. verbeeki Zone the carbonates are overlain by siliceous red shales although the boundary is not seen (Fig. 2).

A summary of the Fusuline Assemblage Zones is shown in Fig. 6. The characteristic foraminifera and algae are illustrated in Plates 1-9.

\section{PALAEOECOLOGY}

Fusuline foraminifera are abundant and diverse in the algal buildups, shoal and transition zone, and open platform margin environments of Facies 2, where they occur with common Archaeolithoporella, Tubiphytes and a diverse dasycladacean microflora. Algae could have constituted an important food supply as well as providing symbionts to the fusulinid community (Ross, 1974). Abundant schwagerinid, schubertellid, boultonid, staffelld, and some primitive verbeekinoidean species occur in association with encrusting, branching, and tubulate algae forming boundstones, rudstones and grainstones. The dasyclad algae mainly occur in bioclastic packstones. Although the dasycladacean algae are abundant, species diversity varies and this suggests a range from low energy to rather agitated water environments. Dasycladaceans are common in the Sakmarian (Early Permian) within the extended shelf platforms and margin buildups of the Trogkofellimestone in the Southern Alps and Shakhtau Limestone of Central Asia (Flügel, 1985). Fusulinids appear to have thrived best in shallow warm tropical to subtropical, well oxygenated open marine environments in association with algae.

The advanced schwagerinids with large fusiform, subcylindrical tests, thick walls and fluted septa, may have favoured reef margins, or shoal areas. The minute schubertellids and the verbeekinids seem to have preferred relatively lower energy, transition zone or back reef environments where they occur with encrusting and branch algae. For a more detailed discussion see Dawson \& Racey, in press.

In the Middle Permian, the environment changed from platform margin algal buildups and open platform to inner platform and protected lagoon, with common bioherms; corals, calcisponges and algae form much of the bioherm framework. Energy levels were lower and lime mud accumulated. This suggests shallowing of the carbonate platform in the Middle Permian. Neoschwagerinids and verbeekinids are diverse and occur with some advanced schwagerinids, whilst smaller fusulinids are less common, being replaced by smaller foraminifera. Dasycladacean 
algae are common to abundant in the wacke/packstones. The smaller foraminiferal assemblages are similar to those described by Vachard (1990b) from west Sumatra.

The neoschwagerinids, with their thick porous keriothecal wall, thick septa, septula and parachomata seem to have favoured algal-rich environments and may have used these algae as symbionts (Ross, 1974), in lower energy back reef, inner platform and lagoon environments. In general, the verbeekinids, with their thin wall, short and thin septa and septula and dense parachomata, seem to have thrived in calmer, more protected lagoon and inner platform environments. Afghanella with its thin wall, thin septa, septula seems to have been more adapted to both conditions than the associated Pseudodoliolina and Neoschwagerina. Verbeekina, with its rounded shape, delicate wall and thin, long septa occurs in both low energy wacke/packstones and in intertidal/supratidal environments (Dawson \& Racey, in press). Verbeekina may have had a semipelagic, rather than benthonic sessile lifestyle and was transported into intertidal-supratidal environments by currents.

\section{CONCLUSIONS}

The Saraburi Limestone, of the Ratburi Limestone Group from Saraburi, represents a variety of carbonate platform environments including turbidite and slope deposits, platform margin algal buildups, inner platform with patch reefs, protected lagoon, intertidal and supratidal (peritidal). Two regressive sequences, ranging in age from Early Permian (Sakmarian) to early Late Permian (Midian) are recognised.

In the Early Permian (Sakmarian), Archaeolithoporella and Tubiphytes form major carbonate buildups (Dawson et al., in press) resembling those described from the Trogkofel reef (Sakmarian), of the southern Alps (Edwards \& Riding, 1988), the Capitan Reef (Guadalupian) of Texas (Toomey \& Babcock, 1983), the Wolfcampian Boundstone from west Texas (Wahlman, 1985) and the Late Permian Reef from Sichuan, China (Guo \& Riding, 1988). It represents an expanded platform margin liable to wave surges (Toomey \& Babcock, 1983). The diversity of dasycladacean algae within these Early Permian buildups of the East Circum-Pacific Realm (Endo, 1969), suggests deposition in a warm, tropical open marine, shelf/platform environment. The high and fluctuating microfloral diversity of this facies is similar to those described from Khao Phlong Phrab by Endo (1969) and to the Sakmarian shelf margin and shelf lagoon of the Trogkofel Limestone, southern Alps and of the Akiyoshi Limestone in Japan (Flügel, 1985).

In the Early Permian the fusuline fauna shows mixing of Arctic and Tethyan faunas; Robustoschwagerina-NagatoellaPseudofusulina assemblages are regarded as Arctic elements (Ingavat et al., 1980; Ingavat, 1988), whilst the verbeekinoidean fauna belongs to the Tethyan realm. This suggests that the Tethys seaway was still linked with the Arctic until at least the late Early Permian (Yahtashian). This suggestion is supported by the occurrence of a Permian aulacocerid found in the upper part of Facies 2, which has also been found in Belgium and Greenland (Dawson, $1978 \mathrm{~b})$. The disappearance of an Arctic fauna and increasing dominance of a Tethyan fauna, together with the absence of the Misellina-Maklaya-Neoschwagerina bioseries (Figs 5 and 6) during the Bolorian and Kubergandian, supports the idea of a disconformity between Facies 2 and 3 (see Fig. 2). Environmental change thus effected the evolutionary development of the Verbeekinoidea. This period (Yahtashian to Bolorian) coincides with the worldwide marine regression of Vail et al. (1977); see Fig. 6. IngavatHelmcke \& Helmcke (1986) and Ingavat (1988) suggest that tectonic activity during the late Early Permian caused the disappearance of the Arctic fauna and appearance of a dominantly Tethyan fauna during the Middle Permian; this, in turn, had an effect on the provincialism of the fusuline faunas of central Thailand. Diagenetic fabrics, including meniscus and vadose cements (Dawson, 1978a), support this theory by indicating uplift and resubmergence of the lithified limestone during this time period. This may have been caused by an eustatic sea level fall and/or tectonic activity associated with the Ural Orogeny in the Phetchabun belt during the late Early and early Middle Permian (Yahtashian-Bolorian) (Helmcke, 1984; Helmcke et al., 1985; Ingavat-Helmcke, 1986; Ingavat 1988). This event may have created the disconformity between Facies 2 and 3 in this area. Wielchowsky \& Young (1985) also suggest that the distribution of Permian lithofacies in the Phetchabun Fold Belt was largely controlled by eustatic sea level variation and regional tectonic events.

The Conglomerate Formation described by Toriyama \& Kanmera (1977) from the Khao Khao section, lies with angular unconformity on the Mid-Permian Presumatrina schellwieni Zone. The conglomerate clasts contain a Verbeekina-Pseudodoliolina-Chusenella assemblage of the Khao Khao fauna which is also found in Facies 5 of the present study area. Unconformities in this area are therefore to be expected and are generally only of local significance.

During the Middle Permian, the carbonate platform in this region comprised a rather calm, inner platform lagoon, indicating a shallowing of the platform. Coral, algae and calcisponges form patch reef frameworks and occur with dasycladacean algae and phylloid algal mounds. The Tethyan Verbeekinoidea dominate the fusuline assemblages together with some cosmopolitan species of Parafusulina and Schwagerina, and can be correlated with the southern Pamirs, Afghanistan (Vachard, 1990), Turkey, Eastern Europe, Russia, southern China, western Japan (Ingavat et al., 1980), Johore, Malaysia (Igo et al., 1979), west Sumatra and western Kampuchea (Vachard, 1990b).

In the late Murgabian-early Midian a crushed Verbeekinarich horizon is overlain by dolomitised algal mats and red shales in the uppermost part of the section, suggesting a sea level fall which can be correlated with an early Late Permian marine regression (Fig. 6). The crushed Verbeekina 
shells were also found in the Lomsak-Chum Phae highway section (Helmcke \& Kraikhong, 1982) described as a molasse-type limestone facies of the Phetchabun Fold Belt. This bioevent and the extinction of fusulinids of the Ratburi Group in Thailand were discussed by Ingavat-Helmcke \& Helmcke (1986) and Ingavat (1988). They suggest that the flysch was deposited during the orogenic evolution of the Kunan and Phetchabun fold and thrust belts in the Late Permian, which corresponds with a worldwide marine regression (Fig. 6). This event also caused a decrease in the diversity of fusuline fauna in the late Murgabian-early Midian.

The fusuline assemblage zones in this area range from Early Permian (Sakmarian) to early Late Permian (Midian). The eight biofacies assemblages range from Robustoschwagerina to Yabeina zones. The Robustoschwagerina-Nagatoella Zone (Sakmarian) is recorded for the first time from central Thailand providing a continuous biostratigraphic zonation for the carbonate sequence in central Thailand. Fusuline assemblages in the Middle Permian are largely controlled by palaeoenvironmental preferences of individual genera and species.

\section{ACKNOWLEDGEMENTS}

I would like to express my sincere gratitude to: Drs John Whittaker, of the British Museum (Natural History) for his encouragement, valuable advice, discussions on the fusuline biostratigraphic study and for improvements to the manuscript; Dan Bosence, of the Royal Holloway and Bedford New College, for his encouragement, advice and comments on the algae and carbonate sedimentology; Daniel Vachard, of the Université des Science et Techniques de Lille Flandres-Artois, for his comments on biostratigraphy, algae and foraminifera; and Andrew Racey of Geochem Ltd., Chester for his improvements to the text, in particular his input into the carbonate sedimentology and palaeoecology.

I would like to thank Dr Tony Barber of the Southeast Asia Group, Royal Holloway and Bedford New College for assistance in writing the paper, and the University of London Consortium for Geological Research in Southeast Asia for providing finance and facilities.

\section{Manuscript received February 1992 Manuscript accepted November 1992}

\section{REFERENCES}

Baird, A. 1990. Evolution of a Guadalupian Carbonate Platform in Peninsular Thailand. 29th Annual Meeting of the British Sedimentological Research Group, December 1990, 2 (Abstract).

Campbell, K.V. \& Ingavat. R. 1972. Brief note on a Permian fossil plant occurrence near Amphoe Phra Phuttabat, Saraburi, Thailand. Newsletter of the Geological Society of Thailand, 5 (1-4), 26

Dawson, O.T. 1978a. Depositional and diagenetic fabrics of Permian limestone, from Saraburi, central Thailand. Proceedings of the Third Regional Conference on Geology and Mineral Resources,
Bankok, November 1978, 47-60.

Dawson, O.T. 1978b. Permian aulacocerid from central Thailand. Ibid., 66-68.

Dawson, O., Baird, A. \& Bosence, D. In press. No massive reefrimmed margin to the Permian carbonate platforms of Thailand. Proceedings of the Seventh Regional Conference on Geology and Energy Resources of Southeast Asia, GEOSEA 7

Dawson, O. \& Racey, A. In press. Fusuline and calcareous algal palaeoecology of the Permian carbonates from Saraburi, central Thailand. Ibid.

Edwards, D.C. \& Riding, R. 1988. Permian Reefs: Aragonite cement or neomorphosed algal skeleton? Ninth IAS Regional Meeting on Sedimentology, Leuven 1988, 50-51.

Endo, R. 1969: Fossil algae from Khao Phlong Phrab district in Thailand. Geology and Palaeontology of Southeast Asia, 7, 33-87.

Flügel, E. 1981. Lower Permian Tubiphytes/Archaeolithoporella buildups in the Southern Alps (Austria and Italy). In: Toomey, D.F. (Ed.), European fossil reef model. Special Publication of the Society of Economic Paleontologists and Mineralogists. 30, 143-160.

Flügel, E. 1985. Diversity and environments of Permian and Triassic dasycladacean algae. In: Toomey, D.F. \& Nitecki, M.H. (Eds), Paleoalgology: Contemporary research and applications. SpringerVerlag, Berlin \& Heidelberg, 344-351.

Flügel, E., Flügel-Kahler, E., Martin, J.M. \& Martin-Algara, H. 1984. Middle Triassic reef from southern Spain. Facies, 11, 173-218.

Fontaine, H., Vachard, D., Tien, N. \& Vozenin-Serra, C. 1986. Permian System in Southeast Asia. Technical Bulletin of the United Nations ESCAP CCOP, 18, 1-172.

Guo, L. \& Riding, R. 1988. Late Permian reefs, Sichuan, China Ninth IAS Regional Meeting on Sedimentology, Leuven 1988, 88.

Helmcke, D. 1984. The orogenic evolution (Permian-Triassic) of central Thailand: Implication on paleogeographic models for mainland Southeast Asia. Mémoires de la Société Géologique de France, n.s. 147, 83-91.

Helmcke, D. \& Kraikhong, C. 1982. On the geosynclinal and orogenic evolution of central and northeastern Thailand. Journal of the Geological Society of Thailand, 5, 52-74.

Helmcke, D., Weber, K., Ingavat, R. \& Nakornsri, N. 1985. Orogenic evolution of N.E. Thailand during the Upper Paleozoic-Triassic. Proceedings of the Conference on Geological and Mineral Resource Development, Northeast Thailand, Khon Khan University, 41-55.

Igo, H. 1972. Fusulinacean fossils from Thailand, Part 6: Fusulinacean fossils from north Thailand. Geology and Paleontology of Southeast Asia, 10, 63-1166.

Igo, H., Rajah, S. \& Kobayashi, F. 1979. Permian fusulinaceans from the Sungei Sedili Area, Johore, Malaysia. Ibid., 20, 95-118.

Ingavat, R. 1984. On the correlation of the Permian foraminiferal fauna of the western, central, and eastern provinces of Thailand. Mémoires de la Société Géologique de France, n.s. 147, 93-100.

Ingavat, R. 1988. Evolution and extinction of the Permian fusulinacean faunas of Thailand. Geological and Mineral Resources of Thailand, Annual Technical Meeting, Chaing Mai University, 111 .

Ingavat, R. \& Douglass, R.C. 1981. Fusuline fossils from Thailand, Part 14: The fusulinid genus Monodiexodina from northwest Thailand. Geology and Paleontology of Southeast Asia, 22, 23-34.

Ingavat-Helmcke, R. \& Helmcke, D. 1986. Permian fusulinacean fauna of Thailand - event controlled evolution. In: Walliser, O.H. (Ed.), Lecture notes on Earth Sciences, Global Bio-events. Vol. 8 Springer-Verlag, Berlin \& Heidelberg, 241-248.

Ingavat R., Toriyama, R. \& Pitakpaivan, K. 1980. Fusuline zonation and fauna characteristics of the Ratburi Limestone in Thailand and its equivalents in Malaysia. Geology and Paleontology of Southeast Asia, 21, 43-62.

Kanmera, K., Ichi, K. \& Toriyama, R. 1976. The evolution and 
extinction patterns of Permian fusulinaceans. Ibid., 17, 118-129.

Kanmera, K. \& Mikami, T. 1965. Fusuline zonation of Lower Permian Zukamatzawa Series. Memoir of the Faculty of Science, Kyushu University, (D), 16, 275-320.

Kanmera, K. \& Toriyama, R. 1968. Fusulinacean fossils from Thailand, Part 3: Maklaya, new generic designation for neoschwagerinids of the group of Cancellina pamirica Leven. Ibid., 5, 31-46.

Leven, E. Ya. 1981. Permian Tethys stage scale and correlation of section of the Mediterranean-Alpine folded belt. IGCP Project 5 Newsletter, 3, 100-112.

Ozawa, T. 1970a. Notes on the phylogeny and classification of the Superfamily Verbeekinoidea (Study of the Permian verbeekinoid, part 1). Memoir of the Faculty of Science, Kyushu University, (D), 20, 17-58.

Ozawa, T. 1970b. Variation and relation growth of Colania douvillei (Ozawa) from the Ratburi Limestone. Geology and Palaeontology of Southeast Asia, 8, 19-41.

Pitakpaivan, K. 1965. Fusulinacean fossils from Thailand, Part 1: Fusulinids of the Ratburi Limestone of Thailand. Memoir of the Faculty of Science, Kyushu University, (D), 23, 117-165.

Pitakpaivan, K. \& Ingavat, R. 1980. Lepidolina multiseptata multiseptata Deprat in Thailand. Geology and Paleontology of Southeast Asia, 21, 37-42.

Ross, C.A. 1974. Evolution and ecological significance of large calcareous Foraminiferida (Protozoa). Proceedings of the Second International Coral Reef Symposium, Great Barrier Reef Committee, Brisbane, 327-333.

Ross, C.A. 1979. Evolution of fusulinacean (Protozoa) in Late Palaeozoic space and time. In: Grey, J. \& Boucot, A.J. (Eds), Historical Biogeography, Plate Tectonics and the Changing Environment. Oregon State University Press, 215-226.

Tittirananda, O.T. 1976. Aspects of Stratigraphy and Palaeontology of the Permian Ratburi limestone of Saraburi, central Thailand. Ph.D. Thesis, University of London. 190pp. [Unpublished].

Toomey, D.F. \& Babcock, J.H. 1983. Precambrian and Palaeozoic algal carbonates, West Texas - Southern New Mexico. Professional Contributions of the Colorado School of Mines, 11, 1-345.

Toriyama, R. 1944. On some fusulinids from Northern Thailand. Japanese Journal of Geology and Geography, 9, 234-247.

Toriyama, R. 1976. Fusuline fossils from Thailand, Part 9: Permian fusulines from Ratburi Limestone in Khao Phlong Phrab area, Saraburi, central Thailand. Geology and Paleontology of Southeast Asia, 17, 1-116.

Toriyama, R. 1978. Fusuline fossils from Thailand, Part 11: Shell destruction of verbeekinids in the fusuline fauna from Khao Khao, Saraburi, central Thailand. Ibid., 19, 29-33.

Toriyama, R. 1984. Summary of the fusuline faunas in Thailand and Malaysia and its equivalents. Ibid., 25, 137-146.

Toriyama, R., Kanmera, K. Kaewbaidhoam, S. \& Hongnusonthi, A.
1974. Biostratigraphic zonation of the Ratburi Limestone in the Khao Phlong Phrab area, Saraburi, central Thailand. Ibid., 14, 2548.

Toriyama, R. \& Kanmera, K. 1977. Fusuline fossils from Thailand, Part 10: The Permian fusulines from the Limestone Conglomerate Formation in the Khao Phlong Phrab area, Saraburi.Ibid., 18, 1-27.

Toriyama, R. \& Kanmera, K. 1979. Fusuline fossils from Thailand, Part 12: Fusulines from the Ratburi Limestone in the Khao Khao area, Saraburi, central Thailand. Ibid., 20, 23-93.

Toriyama, R. and others. 1975. The Carboniferous and Permian systems in Thailand and Malaysia. Ibid., 15, 39-76.

Toriyama, R. \& Pitakpaivan, K. 1973. Fusulinacean fossils from Thailand, Part 7: Middle Permian fusulines from Wat Kirinakratanaram, central Thailand. Ibid., 12, 43-61. 5-6.

Toriyama, R., Pitakpaivan, K. \& Ingavat, R. 1978. The paleogeographic characteristics of fusuline faunas of the Ratburi Group in Thailand and its equivalents in Malaysia. In: Nutalaya, P. (Ed.), Proceedings of the third Regional Conference on Geology and Mineral Resources of Southeast Asia, Bangkok, 107-111.

Vachard, D. 1990a. Téthys et Gondwana au Paleozoique superieur: les donnees afghanes. Biostratigraphie, micropaléontologie, paleogeographie. Documents et Travail IGAL, Paris, 1-463.

Vachard, D. 1990b. Fusulinoids, smaller foraminifera and pseudoalgae from Southeast Kelatan (Malaysia) and their biostratigraphic and paleogeographic value. In: Fontaine, $\mathrm{H}$. (Ed.). Ten years of CCOP Research on the Pre-Tertiary of East Asia. Technical Publications of the United Nations CCOP, 20, 143167.

Vail, P.R., Mitchem, R.M. Jr. \& Thomas, S. III. 1977. Seismic stratigraphy and global changes of sea level, Part 4: Global cycles of relative changes of sea level. In: Payton, C.E. (Ed.), Seismic stratigraphy applications to hydrocarbon exploration. Memoirs of the American Association of Petroleum Geologists, 26, 83-97.

Wahlam, G.P. 1985. Lower Permian (Wolfcampian) Archaeolithoporella-Tubiphytes sponge boundstones from subsurface of West Texas. In: Toomey, D.F. \& Nitecki, M.H. (Eds), Paleoalgology: Contemporary Research and Applications. Springer-Verlag, Berlin \& Heidelberg, 208-215.

Wielchowsky, C.C. \& Young, J.D. 1985. Regional facies variation in Permian rocks of the Phetchabun fold and thrust belt, Thailand. Proceedings of the Conference on Geology and Mineral Resources, Northeast Thailand, Khon Khan University, 41-55.

Winkel, R., Ingavat, R. \& Helmcke, D. 1983. Facies and stratigraphy of the Lower-lower Middle Permian strata of the Phetchabun fold-belt in central Thailand. Proceedings of the Workshop on Stratigraphic Correlation of Thailand and Malaysia, Haad Yai, 1, 293306. 